\title{
Hydrologic Aspects of the 1998-99 Drought in the Delaware River Basin
}

Water-Resources Investigations Report 00-4112 


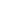


U.S. Department of the Interior

U.S. Geological Survey

\section{HYDROLOGIC ASPECTS OF THE 1998-99 DROUGHT IN THE DELAWARE RIVER BASIN}

by Gary N. Paulachok, Bruce E. Krejmas, and Heidi L. Soden

Water-Resources Investigations Report 00-4112

Milford, Pennsylvania

2000 


\title{
U.S. DEPARTMENT OF THE INTERIOR
}

\section{BRUCE BABBITT, Secretary}

\author{
U.S. GEOLOGICAL SURVEY \\ Charles G. Groat, Director
}

The States of Delaware and New Jersey, the Commonwealth of Pennsylvania, and the City of New York, through their funding of the Office of the Delaware River Master, provided financial support for this report.

For additional information write to:

Delaware River Master

U.S. Geological Survey

Milford Professional Park

Building 3, Suite 304

10 Buist Road

Milford, PA 18337-9311
Copies of this report may be purchased from:

U.S. Geological Survey

Branch of Information Services

Box 25286, Federal Center

Denver, CO 80225-0286

Telephone: 1-888-ASK-USGS 


\section{CONTENTS}

Page

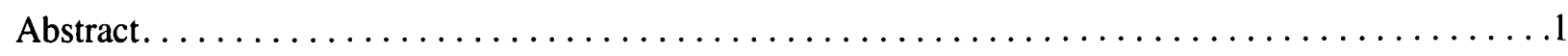

Introduction. . . . . . . . . . . . . . . . . . . . . . . . .

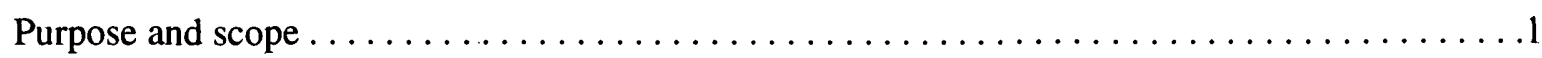

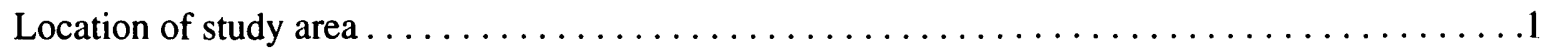

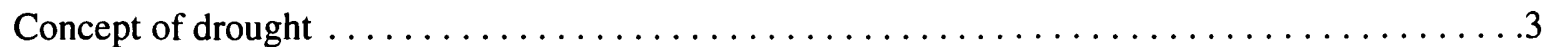

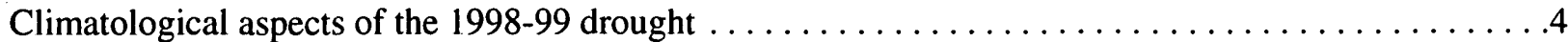

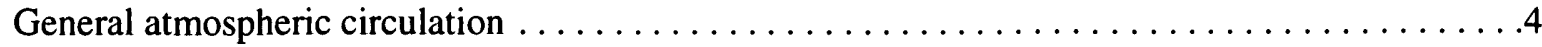

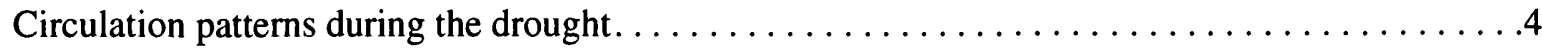

Hydrologic conditions associated with the $1998-99$ drought $\ldots \ldots \ldots \ldots \ldots \ldots \ldots \ldots \ldots \ldots$

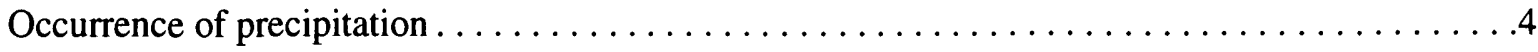

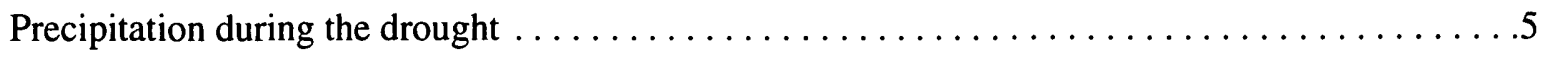

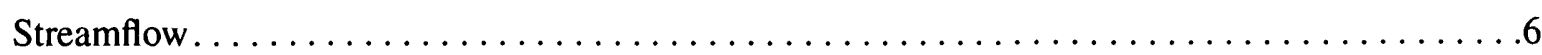

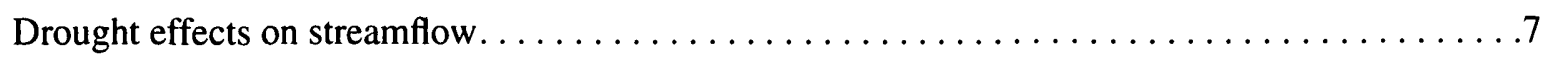

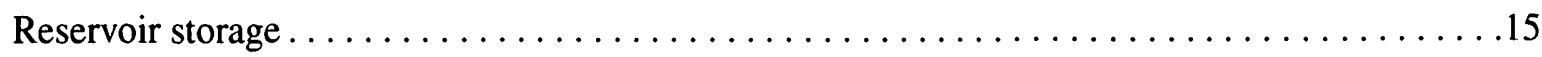

Ground-water occurrence and levels . . . . . . . . . . . . . . . . . . . . . . . .

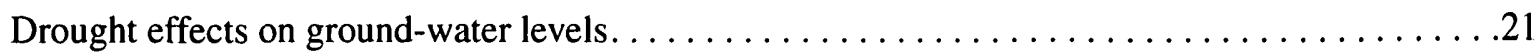

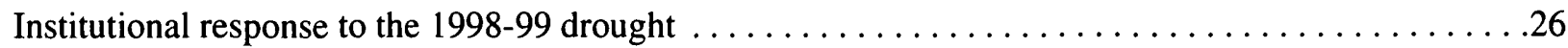

Summary . . . . . . . . . . . . . . 28

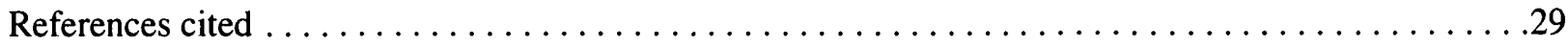

\section{ILLUSTRATIONS}

Figure 1. Map showing the Delaware River Basin and location of index streamflow-

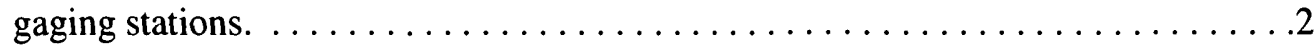

2. Sketch showing propagation of precipitation deficiencies through major components of the hydrologic cycle . . . . . . . . . . . . . . . . . 3

3. Graphs of actual and normal precipitation, and cumulative precipitation deficit in the Delaware River Basin above Trenton, N.J., July 1998 to September 1999. . . . . .6 


\section{ILLUSTRATIONS}

4-5. Hydrographs of:

4. Daily mean discharge at index gaging stations in the Delaware River Basin during water year 1999 and water year of minimum annual mean discharge. . . . . . . . . . . . . . . . . .

5. Daily mean discharge at index gaging stations in the Delaware River Basin during water year 1999 and minimum and median daily mean discharges for period of record prior to water year 1999

6. Graphs of monthly mean discharge for four selected drought years and period of record prior to water year 1999, Flat Brook near Flatbrookville, N.J. . . . 11

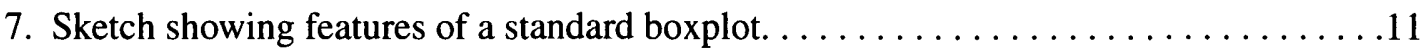

8. Boxplots showing streamflow distributions for index gaging stations in the

Delaware River Basin. . . . . . . . . . . . . . . . . . . . . . 12

9. Graphs of streamflow trends at index gaging stations in the Delaware River Basin. . . . 14

10. Plots of flow-duration curves for three selected index gaging stations in the

Delaware River Basin. . . . . . . . . . . . . . . . . . . . . . . . . . . 15

11. Maps showing streamflow conditions in the Delaware River Basin before and after

Tropical Storm Floyd. . . . . . . . . . . . . . . . . . . . . 16

12-13. Graphs of:

12. Actual contents and operating curves for New York City reservoirs in the Delaware River Basin, January 1, 1998, to December 31, 1999.. . . . . 18

13. Actual contents and operating curves for New York City reservoirs in the Delaware River Basin, June 1, 1984, to December 31, 1985.. . . . . . . 19

14. Map showing location of selected observation wells operated by the U.S.

Geological Survey in the Pennsylvania part of the Delaware River Basin........21

15-16. Hydrographs of:

15. Ground-water levels in three observation wells in the Delaware River Basin

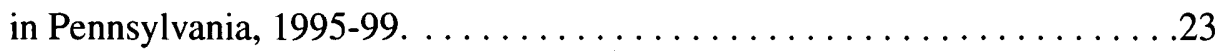

16. Ground-water levels in observation well CH-10, Chester County, Pennsylvania,

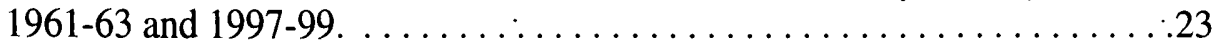

17. Boxplots showing distribution of ground-water levels in observation well $\mathrm{CH}-10$, Chester County, Pennsylvania, 1963 and $1999 . \ldots \ldots \ldots \ldots \ldots \ldots \ldots \ldots . \ldots \ldots$

18. Maps showing ground-water levels in observation wells in the Pennsylvania part of the Delaware River Basin for six selected months during the 1998-99 drought. . . . .25 


\section{TABLES}

Table 1. Monthly and normal precipitation for selected locations in the Delaware River Basin, 1998-99. . . . . . . . . . . . . . . . . . . . . . . . . 5

2. Ranking of selected minimum annual mean streamflows for index gaging stations in the Delaware River Basin. . . . . . . . . . . . . . . . . . . . . . . . 7

3. Summary data on low streamflows during period of record prior to water year 1999 and water year 1999 for index gaging stations in the Delaware River Basin. . . . . 17

4. Summary data on annual n-day minimum streamflows during the 1998-99 drought and record low $n$-consecutive day values at index gaging stations in the Delaware River Basin. . . . . . . . . . . . . . . . . . . . . . 18

5. Summary data on combined storage for New York City reservoirs in the Delaware River Basin, June 1998 - December 1999.. . . . . . . . . . . . . . . . . . . 20

6. Comparison of record low ground-water levels with low levels during the 1998-99

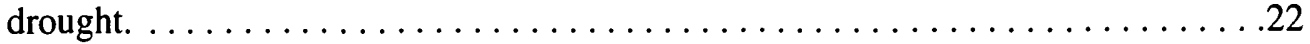

\section{CONVERSION FACTORS AND ABBREVIATIONS}

\section{Multiply}

inch (in.)

foot $(\mathrm{ft})$

mile (mi)

square mile $\left(\mathrm{mi}^{2}\right)$

million gallons (Mgal)

million gallons (Mgal)

billion gallons (Bgal)

cubic foot per second-day $\left(\mathrm{ft}^{3} / \mathrm{s} \cdot \mathrm{d}\right)$

billion gallons per day (Bgal/d)

cubic foot per second $\left(\mathrm{ft}^{3} / \mathrm{s}\right)$

cubic foot per second

per square mile $\left[\left(\mathrm{ft}^{3} / \mathrm{s}\right) / \mathrm{mi}^{2}\right]$
By

To obtain

\section{Length}

25.4

0.3048

1.609

$2 . \underline{\text { Area }}$

Volume

3,785

1.547

3.785

0.002447

\section{Flow rate}

43.81

0.02832

0.011 millimeter

meter

kilometer

square kilometer

cubic meter

cubic foot per second-day

cubic hectometer

cubic hectometer

cubic meter per second cubic meter per second cubic meter per second per square kilometer 



\title{
HYDROLOGIC ASPECTS OF THE 1998-99 DROUGHT IN THE DELAWARE RIVER BASIN
}

\author{
by Gary N. Paulachok, Bruce E. Krejmas, and Heidi L. Soden
}

\begin{abstract}
A notable drought in the Delaware River Basin during late 1998 and most of 1999 had a major effect on surface and subsurface components of the hydrologic system. The drought conditions resulted from anomalous patterns in the general atmospheric circulation that diverted Gulf and subtropical Atlantic moisture away from the basin. From September 1998 to August 1999, the accumulated precipitation deficiency was greater than 12 inches in the part of the basin above Trenton, N.J. Flows in some streams, mainly in the middle and lower parts of the basin, decreased to levels near or less than those measured during the drought of the 1960's, the most severe drought of record in the basin. On several dates in August 1999, combined storage in three New York City water-supply reservoirs in the upper Delaware River Basin decreased by more than 2 billion gallons per day. The drought had a pronounced effect on ground-water levels, as the combination of below-normal recharge and elevated rates of evapotranspiration produced abnormal water-level declines and record low water levels in much of the basin. The drought was broken in mid-September 1999 when the remnants of Tropical Storm Floyd delivered drenching rains throughout the basin.
\end{abstract}

\section{INTRODUCTION}

Exceptionally dry conditions dominated the Middle Atlantic region and the northeastern United States during late 1998 and most of 1999. In the Delaware River Basin, as in other parts of the region, the hydrologic system showed a pronounced response to the precipitation deficiency. Below-normal amounts of rainfall, snowfall, and runoff, and unusually low streamflows and ground-water levels, were prevalent. In summer 1999 , the dryness was compounded by excessively high temperatures, which intensified the drought conditions. In September 1999, the remnants of Tropical Storm Floyd moved across the region and delivered drenching rains to the basin, breaking the drought conditions. Whether these rains ended the drought or merely interrupted a longer-term event will depend upon future weather conditions.

\section{Purpose and Scope}

The drought of 1998-99 affected, in varying degrees, a broad area from Virginia to Maine. The Delaware River Basin, which occupies part of that area, was particularly hard hit and is the focus of this report. The report documents the precipitation deficiency associated with the drought and examines the response of the hydrologic systemnamely, reductions in streamflow and reservoir storage, and declines in ground-water levels-to the deficiency. The report does not address water-management and non-hydrologic aspects of the drought, including those concerned with agricultural, sociological, and economic issues and impacts.

\section{Location of Study Area}

The Delaware River Basin comprises a land area of $12,967 \mathrm{mi}^{2}$ in New York, Pennsylvania, New Jersey, Delaware, and a small part of northeastern Maryland (fig. 1). The river originates in the Catskill Mountains of New York, as the East and West Branches of the Delaware River, and flows for about $370 \mathrm{mi}$ on a generally southsoutheasterly course to its mouth at Delaware Bay. The basin lies between the Susquehanna River Basin to the west and the Hudson, Passaic, and Raritan River Basins to the east. The Mongaup and Neversink Rivers in New York; the Lackawaxen, Lehigh, and Schuylkill Rivers in Pennsylvania; the Maurice and Musconetcong Rivers and Rancocas Creek in New Jersey; and the Christina River in Delaware are the major tributaries of the Delaware River. The localities of Port Jervis, New York; Easton, Philadelphia, Chester, Allentown, and Reading, $\mathrm{Pa}$.; Trenton and Camden, N.J.; and Wilmington, Del., are the major cities in the Delaware River Basin. 

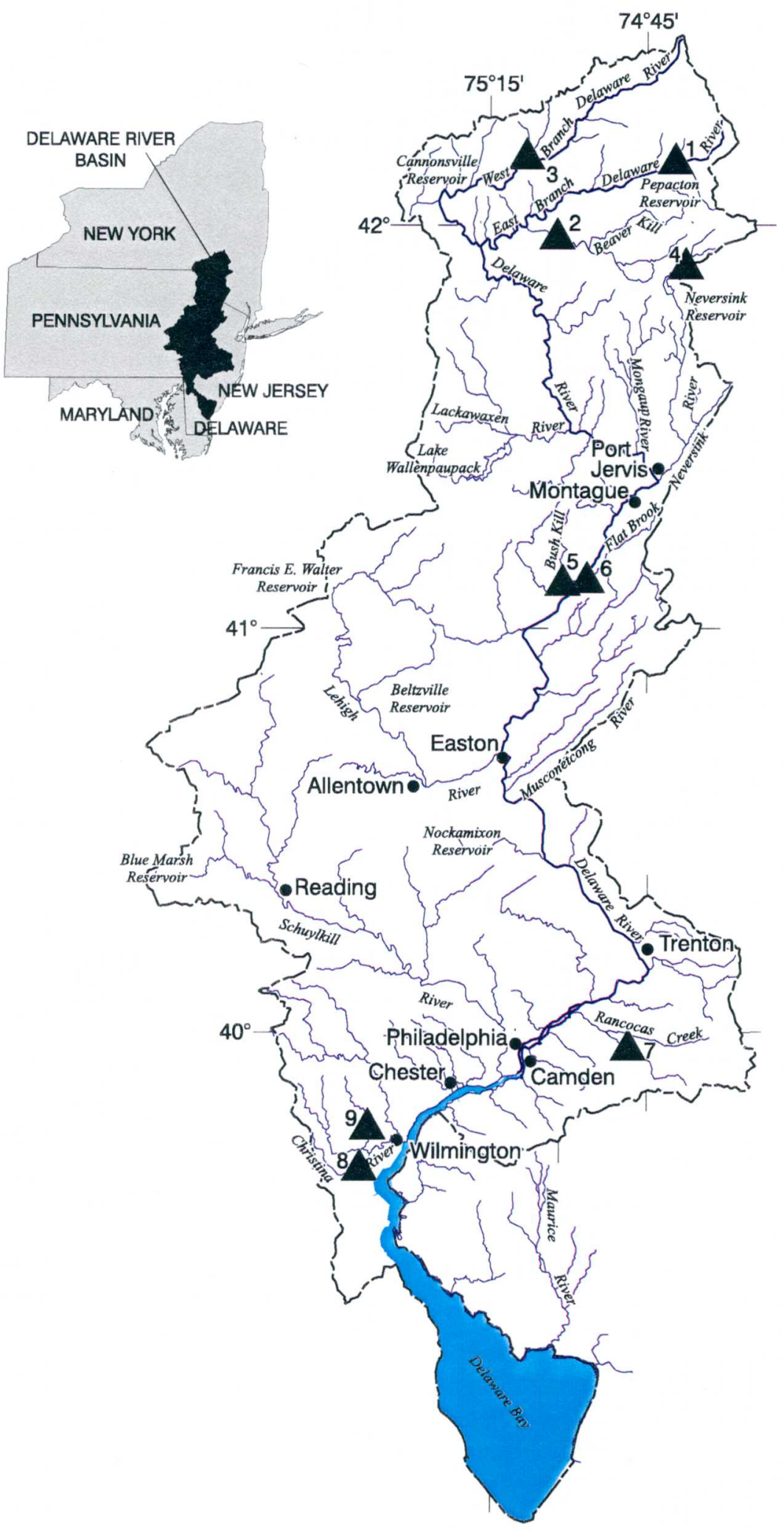

Figure 1. The Delaware River Basin and location of index streamflow-gaging stations. 
The Delaware River provides water for municipal, industrial, and other uses for more than 7 million basin residents. In addition, a 1954 Supreme Court Decree authorized diversions of water from the Delaware River Basin to New York City and out-of-basin parts of New Jersey; these diversions provide water to nearly 10 million people who live outside the basin. New York City, the largest importer of Delaware River water, obtains about one-half of its total water supply from three large reservoirs-Pepacton, Cannonsville, and Neversink-located in the upper Delaware River Basin (fig. 1).

\section{Concept of Drought}

Drought is a natural, recurring, and temporary feature of climate. Although drought can be defined from several discipline-based perspectives including meteorology, hydrology, and agriculture, the central theme in the definitions is the concept of a water deficiency. Drought is difficult to define precisely, however, because of the need to identify the specific components of the hydrologic cycle affected by the deficiency and the time period associated with it. Figure 2 illustrates the propagation of the effects of two hypothetical precipitation deficiencies through the surface-runoff, soil-moisture, streamflow, and ground-water components of the hydrologic cycle. From this perspective, precipitation can be considered the carrier of the drought signal, and streamflow and ground-water levels can be considered the last indicators of drought occurrence (Hare, 1987; Klemes, 1987).

This report is concerned with aspects of hydrologic drought in the Delaware River Basin.

According to the World Meteorological Organization, a hydrologic drought is defined in terms of reduction of streamflows, reduction in lake or reservoir storage, and lowering of ground-water levels (Subrahmanyam, 1967). Because the subject matter of this report is bounded by this definition, the report describes only several aspects of the complex and wide-ranging phenomenon of drought.

Historically, the Delaware River Basin has been affected by numerous episodes of drought. Severity and duration are the main factors that distinguish one drought from another. The most serious drought affected the northeastern United

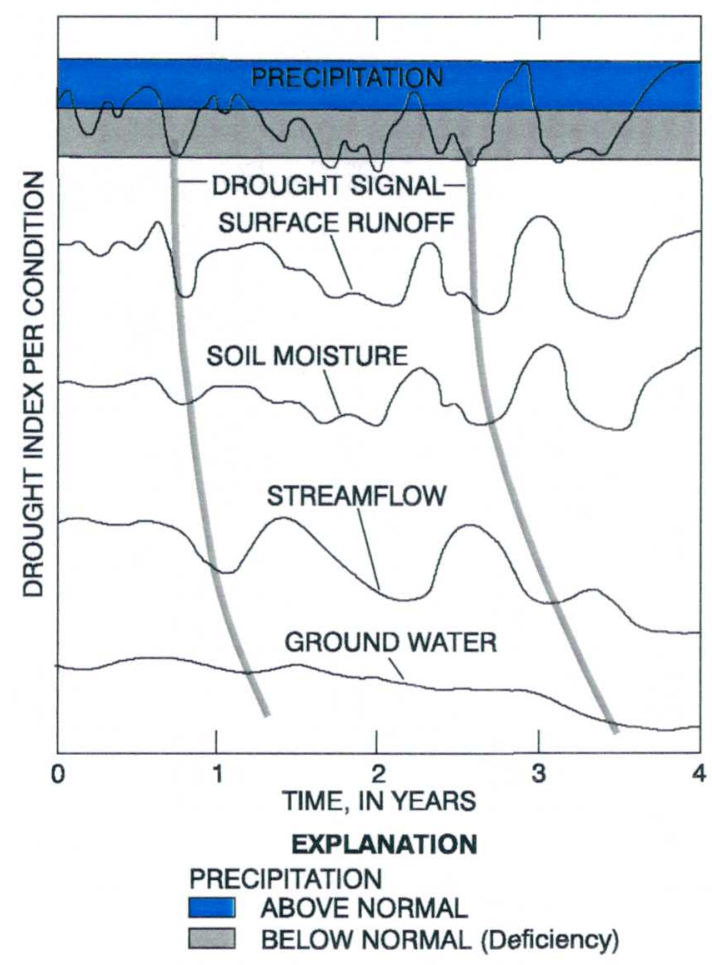

Figure 2. Propagation of precipitation deficiencies through major components of the hydrologic cycle (Modified from Changnon, 1987).

States, including the Delaware River Basin, in the 1960's. The 1961-67 drought in the Northeast was the longest and most severe in the recorded history of the region, and it affected human activities mainly by its impact on water resources related to agriculture and water supplies (Barksdale and others, 1966). The Water Resources Council (1966) estimated that in the Northeast, a drought of this duration occurs, on the average, once in about 160 years. Although drought conditions eased at different times in different parts of the region, the drought was not completely broken until spring 1967. The Delaware River Basin also was affected by droughts in 1980-82 and 1984-85, and by several transitory droughts in the 1990's. The drought of 1998-99, characterized by a substantial precipitation shortfall and intense heat, was one of the most severe short-term droughts of the 20th century. 


\section{CLIMATOLOGICAL ASPECTS OF THE 1998-99 DROUGHT}

\section{General Atmospheric Circulation}

The weather in the Delaware River Basin is characterized by seasonal changes typical of a temperate humid climate. The Atlantic Ocean to the east moderates temperature extremes to a certain extent, but this effect is not always evident because prevailing winds are westerly. Storms moving parallel to the Atlantic coast from the Gulf of Mexico are important precipitation-producing systems during the winter months. In summer, warm, moist air is circulated into the area by the Bermuda high and scattered convective showers contribute the bulk of the precipitation. Occasionally, tropical storms move through the area. The large rainfall totals associated with these storms interrupt the otherwise generally even distribution of precipitation throughout the year.

\section{Circulation Patterns During the Drought}

Droughts are associated with persistent or persistently recurring atmospheric circulation patterns (Namias, 1985). These patterns, which produce little or no precipitation, are not associated with any discernibly unique feature of individual daily circulation patterns. When averaged for a month or more during a drought, however, the atmospheric circulation patterns begin to reveal anomalies when compared to long-term average patterns.

The progressive development of drought conditions in the Delaware River Basin from summer 1998 to fall 1999 resulted from anomalous patterns in the general atmospheric circulation. During this period, no single factor was responsible for the reduction of atmospheric moisture. Rather, two factors-northerly displacement of the jet stream and westerly displacement of Gulf and subtropical Atlantic moisture- played important roles in diverting atmospheric moisture away from the basin.

By late spring 1999, the jet stream, which forms a boundary between cool polar air and warm tropical air, was located farther north than normal, steering most precipitation systems to the north of the Delaware River Basin. Occasionally during the drought period, the jet stream split into two distinct streams, causing storms to pass to the north and south of the basin.

The lack of Gulf and subtropical Atlantic moisture entering the region was a major reason for the lack of significant rainfall. During the drought, the flow of moisture from lower latitudes often was weak and migrated further west than normal. During summer 1999, many parts of the Delaware River Basin received little rain as Gulf and subtropical moisture moved into areas west of the Appalachian Mountains.

By September 1999, the jet stream shifted into a southwest to northeast orientation and allowed tropical storms to move inland and deliver much-needed rain. Without question, hydrologic conditions in the Delaware River Basin would have continued to deteriorate if Tropical Storm Floyd had not delivered unusually large amounts of rain to the basin in mid-September.

\section{HYDROLOGIC CONDITIONS ASSOCIATED WITH THE 1998-99 DROUGHT}

As a result of the precipitation deficiency associated with the 1998-99 drought, water resources in surface and subsurface systems came under considerable stress. This section documents the precipitation shortfall and examines the resulting effects on streamflows, reservoir storage, and ground-water levels.

\section{Occurrence of Precipitation}

Precipitation is the source of all fresh water in the Delaware River Basin. Mean annual precipitation ranges from less than 40 in. in some southern and western parts of the basin to more than $50 \mathrm{in}$. in some northern parts, where terrain effects have an important local influence on precipitation delivery. During the warmer months, much of the precipitation input is returned to the atmosphere through evapotranspiration while during the cooler months, water loss is greatly reduced. Precipitation delivered as snow may be stored temporarily in snowpack. Water in frozen form may be returned to the atmosphere directly through sublimation or may eventually melt, providing seasonal runoff to streams and recharge to ground-water reservoirs. 


\section{Precipitation During the Drought}

Precipitation data discussed in this report are for the part of the Delaware River Basin located north of Trenton, N.J. (fig. 1). The values given are arithmetic means of amounts measured at several recording and non-recording stations in New York, New Jersey, and Pennsylvania. No attempt has been made to estimate areal mean precipitation by use of weighting factors or other computational techniques. These data, along with point-precipitation data for recording stations at Allentown, Pa., Philadelphia, Pa., and Wilmington, Del., are presented in table 1 . In general, precipitation totals during 1998-99 were greater in the northern and southern parts of the basin than in the central part.

In the Delaware River Basin, generally dry conditions prevailed during fall and winter 1998, setting the stage for drought conditions during summer and fall 1999. Antecedent conditions reflected a precipitation surplus, however, as precipitation from August 1997 to July 1998 was nearly 6 in. greater than normal (in this report, the term "normal", in the context of precipitation, refers to average precipitation during 1961-90), and from April to July 1998 precipitation was more than 4 in. above normal. The deficient precipitation trend began in July 1998 (fig. 3), as monthly precipitation totals dropped below normal and remained at below-normal levels through December 1998. An exception to this trend was the October total, when precipitation was slightly above normal. In December 1998, precipitation in the basin was 32 percent of normal. Monthly precipitation amounts in November and December 1998 were small, and the total for the two months was only 2.78 in.

Table 1. Monthly and normal precipitation for selected locations in the Delaware River Basin, 1998-99

[All figures reported in inches. Normals for all locations are for 1961-90 except above Montague, N.J., which is for 1941-94. Data for all locations except above Montague from National Weather Service]

\begin{tabular}{|c|c|c|c|c|c|c|c|c|c|c|}
\hline \multirow[t]{2}{*}{ Date } & \multicolumn{2}{|c|}{$\begin{array}{l}\text { Multi-station } \\
\text { average above } \\
\text { Montague, N.J. }\end{array}$} & \multicolumn{2}{|c|}{ Allentown, $\mathrm{Pa}$. } & \multicolumn{2}{|c|}{$\begin{array}{l}\text { Multi-station } \\
\text { average above } \\
\text { Trenton, N.J. }\end{array}$} & \multicolumn{2}{|c|}{ Philadelphia, Pa. } & \multicolumn{2}{|c|}{ Wilmington, Del. } \\
\hline & Total & Normal & Total & Normal & Total & Normal & Total & Normal & Total & Normal \\
\hline \multicolumn{11}{|l|}{1998} \\
\hline Jan. & 3.73 & 2.88 & 3.42 & 3.16 & 4.15 & 3.20 & 4.24 & 3.18 & 4.51 & 3.11 \\
\hline Feb. & 2.96 & 2.69 & 3.71 & 2.95 & 3.68 & 2.83 & 3.25 & 2.81 & 2.87 & 2.99 \\
\hline Mar. & 4.04 & 3.30 & 4.00 & 3.28 & 4.28 & 3.74 & 3.93 & 3.86 & 5.23 & 3.87 \\
\hline Apr. & 4.67 & 3.77 & 5.22 & 3.52 & 4.97 & 3.89 & 2.70 & 3.47 & 2.94 & 3.39 \\
\hline May & 4.82 & 4.20 & 4.58 & 4.20 & 5.43 & 3.71 & 3.87 & 3.18 & 4.13 & 3.23 \\
\hline June & 7.52 & 3.92 & 4.95 & 3.75 & 6.90 & 3.71 & 4.92 & 3.92 & 4.66 & 3.51 \\
\hline July & 3.62 & 4.09 & 1.18 & 4.14 & 2.90 & 3.99 & 1.79 & 3.88 & 2.18 & 3.90 \\
\hline Aug. & 1.42 & 3.98 & 3.13 & 4.28 & 2.35 & 4.28 & 1.26 & 4.10 & 3.14 & 4.03 \\
\hline Sept. & 2.97 & 3.72 & 2.99 & 3.93 & 2.72 & 3.95 & 1.86 & 3.42 & 1.78 & 3.59 \\
\hline Oct. & 3.36 & 3.39 & 4.50 & 2.94 & 3.89 & 3.52 & 1.84 & 2.83 & 2.81 & 2.89 \\
\hline Nov. & 1.35 & 3.86 & 1.39 & 3.88 & 1.64 & 3.83 & 1.18 & 3.32 & 1.27 & 3.33 \\
\hline Dec. & 1.32 & 3.38 & .64 & 3.49 & 1.14 & 3.58 & .82 & 3.45 & 1.04 & 3.54 \\
\hline Total & 41.78 & 43.18 & 39.71 & 43.52 & 44.05 & 44.23 & 31.66 & 41.42 & 36.56 & 41.38 \\
\hline \multicolumn{11}{|l|}{1999} \\
\hline Jan. & 5.33 & 2.88 & 5.42 & 3.16 & 6.44 & 3.20 & 4.89 & 3.18 & 5.42 & 3.11 \\
\hline Feb. & 1.60 & 2.69 & 2.67 & 2.95 & 1.90 & 2.82 & 2.95 & 2.81 & 3.51 & 2.99 \\
\hline Mar. & 4.37 & 3.30 & 3.07 & 3.28 & 4.55 & 3.74 & 4.02 & 3.86 & 3.96 & 3.87 \\
\hline Apr. & 2.22 & 3.77 & 1.41 & 3.52 & 2.46 & 3.89 & 4.19 & 3.47 & 3.37 & 3.39 \\
\hline May & 3.17 & 4.20 & 5.06 & 4.20 & 3.20 & 3.71 & 2.82 & 3.18 & 3.58 & 3.23 \\
\hline June & 2.02 & 3.92 & .98 & 3.75 & 1.85 & 3.71 & 1.16 & 3.92 & 1.61 & 3.51 \\
\hline July & 1.71 & 4.09 & .33 & 4.14 & 1.64 & 3.99 & 1.22 & 3.88 & .89 & 3.90 \\
\hline Aug. & 3.05 & 3.98 & 3.82 & 4.28 & 3.67 & 4.28 & 5.32 & 4.10 & 4.25 & 4.03 \\
\hline Sept. & 9.08 & 3.72 & 11.57 & 3.93 & 10.01 & 3.95 & 13.07 & 3.42 & 12.68 & 3.59 \\
\hline Oct. & 2.72 & 3.39 & 2.52 & 2.94 & 2.66 & 3.52 & 3.55 & 2.83 & 3.45 & 2.89 \\
\hline Nov. & 2.98 & 3.86 & 2.43 & 3.88 & 3.31 & 3.83 & 2.31 & 3.32 & 2.11 & 3.33 \\
\hline Dec. & 1.63 & 3.38 & 2.45 & 3.49 & 2.01 & 3.58 & 2.99 & 3.45 & 1.85 & 3.54 \\
\hline Total & 39.88 & 43.18 & 41.73 & 43.52 & 43.70 & 44.23 & 48.49 & 41.42 & 46.68 & 41.38 \\
\hline Total, $98+99$ & 81.66 & & 81.44 & & 87.75 & & 80.15 & & 83.24 & \\
\hline
\end{tabular}




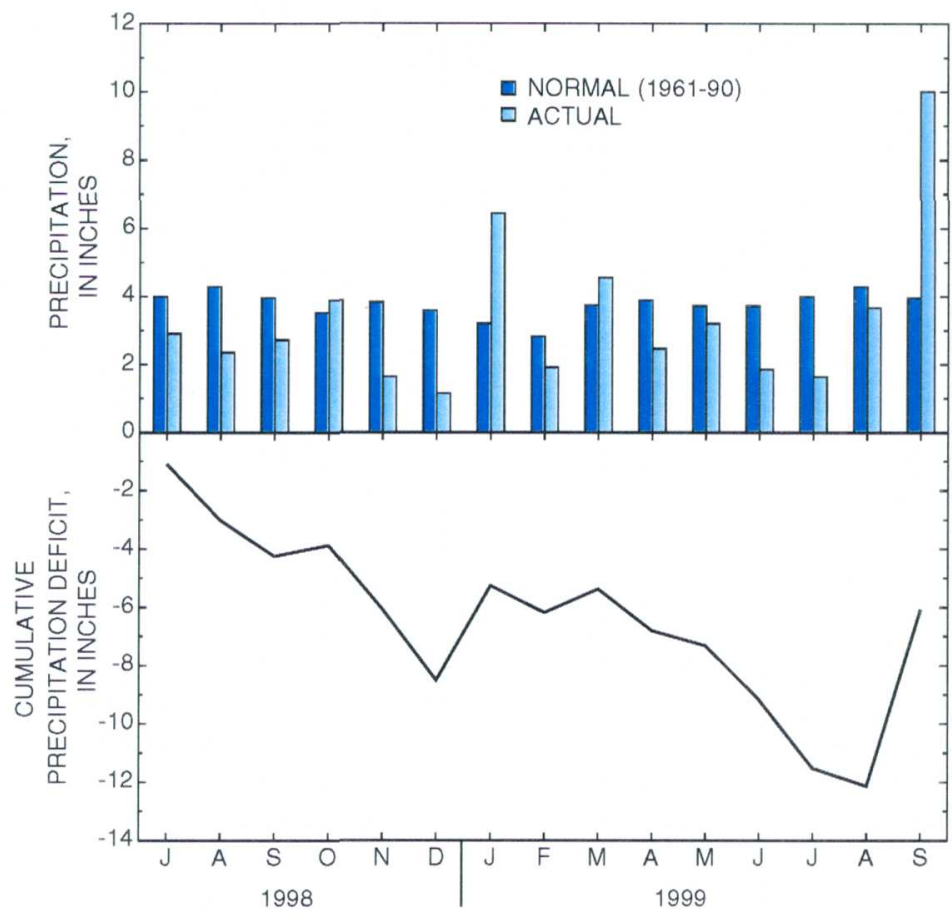

Figure 3. Actual and normal precipitation, and cumulative precipitation deficit in the Delaware River Basin above Trenton, N.J., July 1998 to September 1999.

Precipitation was above normal in January and March 1999, but in February 1999 and from April to August 1999 , monthly totals were below normal. As a result of these many shortfalls, the accumulated precipitation deficiency increased quickly. In August 1998, precipitation during the previous 12 months was several inches greater than normal. By August 1999, however, precipitation during the previous 12 months was 12.14 in. less than normal. For the period April 1999 to August 1999, the accumulated precipitation deficiency was 6.76 in. Despite the soaking rains delivered by the remnants of Tropical Storm Floyd on September 16, 1999, all 12-previous month accumulated precipitation totals for the months from September 1999 to April 2000 remained in the deficient range.

The amount of snow in the upper Delaware River Basin is an important factor in the water balance. The snowpack acts as a natural reservoir, storing water in winter and releasing it in spring. Depending on the amount of snow and the timing of melting, snowmelt can be an important source of runoff to streams and recharge to ground-water reservoirs.
During most of winter 1998-99, the snowpack in the upper Delaware River Basin was below normal. Snowfall was greatest in January 1999 but the snow melted shortly thereafter. Because the snowpack stored relatively little water and released the water quickly, the water-supply benefits of the snowmelt were marginal and transitory. Like the below-normal amounts of liquid precipitation, the below-normal snowpack was a precursor of the drought conditions that would intensify later in the year.

The drought of 1998-99 was preceded by a period of above-normal precipitation and was broken by Tropical Storm Floyd, which delivered about 5 in. of rain to the northern part of the Delaware River Basin and about 10 in. to the southern part. Because of the timing of wet and dry periods, precipitation totals for 1998 and 1999 fall in the normal range if interpreted on a calendar-year basis. Consequently, the calendar-year totals mask the true magnitude of the precipitation shortfall during the drought period.

\section{Streamflow}

Streamflow in the Delaware River Basin is derived from precipitation that falls within the basin boundaries. Within the basin, about one-half of the average annual precipitation, or nearly 5,000 Bgal, becomes streamflow. An important component of streamflow is baseflow or dryweather flow, which consists mainly of groundwater discharge or releases from surface storage.

The following discussions, illustrations, and tables describe and summarize low streamflows during the drought of 1998-99. Two reference time periods are used in the analysis of the streamflow data. They are the water year, which is the interval from October 1 to September 30, and the climatic year, which is the interval from April 1 to March 31. Customarily, the climatic year is used for low-streamflow analysis in order to incorporate the entire low-flow season into a single 365-day period. 
Discharge records for nine long-term U.S. Geological Survey (USGS) streamflow-gaging stations ("index gaging stations") in New York, New Jersey, Pennsylvania, and Delaware were used in the analysis of low-flow conditions during the drought period. Figure 1 shows the location of these stations. Except for the two stations in Delaware, the index stations are on streams that are unregulated or subject to only minor regulation. Streamflow at White Clay Creek near Newark, Del. (site number 8 on figure 1) is affected by upstream operations of the City of Newark water plant. Low streamflow at Red Clay Creek at Wooddale, Del. (site number 9 on figure 1) is affected at times by flow-augmentation releases from Hoopes Reservoir. In identifying historical records for low-flow analysis, the objective was to select those that, to the extent possible, reflect mainly the effects of climate and natural conditions on streamflow.

\section{Drought Effects on Streamflow}

In the context of streamflow, the drought of 1998-99 in the Delaware River Basin was noteworthy for several reasons. First, it was one of the most severe short-duration droughts of the 20th century. In a relatively short time, minimum daily mean discharges at many gaging stations decreased to levels near or less than those measured during the drought of the 1960's, the most severe drought of record in the basin. On a water-year basis, annual mean streamflow was the 4 th lowest of record at one index gaging station and the 5th lowest of record at two stations. At four other stations, annual mean streamflows ranged from the 8th lowest to the 15th lowest of record (table 2). In addition, in summer 1999, extreme heat compounded the effects on low streamflow, as persistently high temperatures resulted in increased demand for water and greater loss of water by evapotranspiration. Finally, the drought had its greatest effect on streamflow in late summer, as flows receded to minimum levels in August and early September. Although there are exceptions, in the Delaware River Basin, streamflow generally is lowest in early fall.

Table 2. Ranking of selected minimum annual mean streamflows for index gaging stations in the Delaware River Basin [Format is $\frac{f t^{3}}{s} / c f s m$ where $\frac{f t^{3}}{s}$, cubic feet per second; cfsm, cubic feet per second per square mile; wy, water year; >, greater than]

\begin{tabular}{|c|c|c|c|c|c|c|c|c|c|}
\hline \multirow{2}{*}{$\begin{array}{c}\text { Site } \\
\text { number } \\
\text { on figure } \\
1\end{array}$} & \multirow{2}{*}{$\begin{array}{l}\text { USGS station } \\
\text { number }\end{array}$} & \multirow{2}{*}{ Station name } & \multirow{2}{*}{$\begin{array}{l}\text { Drainage } \\
\text { area } \\
\text { (square } \\
\text { miles) }\end{array}$} & \multicolumn{5}{|c|}{ Rank of annual mean streamflow } & \multirow{2}{*}{$\begin{array}{c}\begin{array}{c}\text { Rank of WY } 1999 \\
\text { annual mean } \\
\text { streamflow }\end{array} \\
>5\end{array}$} \\
\hline & & & & 1 & 2 & 3 & 4 & 5 & \\
\hline 1 & 01413500 & $\begin{array}{c}\text { East Branch } \\
\text { Delaware River at } \\
\text { Margaretville, N.Y. }\end{array}$ & 163 & $\begin{array}{c}138 / 0.85 \\
(1965)\end{array}$ & $\begin{array}{c}170 / 1.04 \\
(1985)\end{array}$ & $\begin{array}{c}183 / 1.12 \\
(1962)\end{array}$ & $\begin{array}{c}198 / 1.21 \\
(1944)\end{array}$ & $\begin{array}{c}199 / 1.22 \\
(1966)\end{array}$ & $\begin{array}{l}249 / 1.53 \\
\text { Rank }=14\end{array}$ \\
\hline 2 & 01420500 & $\begin{array}{l}\text { Beaver Kill at } \\
\text { Cooks Falls, N.Y. }\end{array}$ & 241 & $\begin{array}{l}277 / 1.15 \\
(1965)\end{array}$ & $\begin{array}{c}333 / 1.38 \\
(1985)\end{array}$ & $\begin{array}{l}358 / 1.49 \\
(1941)\end{array}$ & $\begin{array}{l}361 / 150 \\
(1962)\end{array}$ & $\begin{array}{l}376 / 1.56 \\
(1944)\end{array}$ & $\begin{array}{c}446 / 1.85 \\
\text { Rank }=15\end{array}$ \\
\hline 3 & 01423000 & $\begin{array}{l}\text { West Branch } \\
\text { Delaware River at } \\
\text { Walton, N.Y. }\end{array}$ & 332 & $\begin{array}{c}263 / 0.79 \\
(1965)\end{array}$ & $\begin{array}{c}340 / 1.02 \\
(1985)\end{array}$ & $\begin{array}{c}362 / 1.09 \\
(1995)\end{array}$ & $\begin{array}{c}391 / 1.18 \\
(1963)\end{array}$ & $\begin{array}{c}400 / 1.20 \\
(1999)\end{array}$ & - \\
\hline 4 & 01435000 & $\begin{array}{c}\text { Neversink River } \\
\text { near } \\
\text { Claryville, N.Y. }\end{array}$ & 66.6 & $\begin{array}{c}100 / 1.51 \\
(1965)\end{array}$ & $\begin{array}{c}116 / 1.75 \\
(1985)\end{array}$ & $\begin{array}{c}121 / 1.82 \\
(1962)\end{array}$ & $\begin{array}{c}132 / 1.99 \\
(1966)\end{array}$ & $\begin{array}{c}135 / 2.03 \\
(1995)\end{array}$ & $\begin{array}{l}147 / 2.21 \\
\text { Rank }=8\end{array}$ \\
\hline 5 & 01439500 & $\begin{array}{c}\text { Bush Kill at } \\
\text { Shoemakers, Pa. }\end{array}$ & 117 & $\begin{array}{l}95.4 / 0.82 \\
(1965)\end{array}$ & $\begin{array}{c}115 / 0.98 \\
(1985)\end{array}$ & $\begin{array}{c}132 / 1.13 \\
(1966)\end{array}$ & $\begin{array}{c}135 / 1.15 \\
(1999)\end{array}$ & $\begin{array}{c}138 / 1.18 \\
(1932)\end{array}$ & - \\
\hline 6 & 01440000 & $\begin{array}{l}\text { Flat Brook near } \\
\text { Flatbrookville, N.J. }\end{array}$ & 64.0 & $\begin{array}{l}43.4 / 0.68 \\
(1965)\end{array}$ & $\begin{array}{l}55.6 / 0.87 \\
(1966)\end{array}$ & $\begin{array}{l}61.8 / 0.96 \\
(1985)\end{array}$ & $\begin{array}{l}64.7 / 1.01 \\
(1932)\end{array}$ & $\begin{array}{c}71.0 / 1.11 \\
(1999)\end{array}$ & - \\
\hline 7 & 01467000 & $\begin{array}{l}\text { North Branch } \\
\text { Rancocas Creek at } \\
\text { Pemberton, N.J. }\end{array}$ & 118 & $\begin{array}{c}92.3 / 0.78 \\
(1995)\end{array}$ & $\begin{array}{c}92.7 / 0.78 \\
(1985)\end{array}$ & $\begin{array}{c}98.8 / 0.84 \\
(1966)\end{array}$ & $\begin{array}{c}103 / 0.87 \\
(1981)\end{array}$ & $\begin{array}{c}107 / 0.91 \\
(1931)\end{array}$ & $\begin{array}{c}125 / 1.06 \\
\text { Rank }=14\end{array}$ \\
\hline 8 & 01479000 & $\begin{array}{l}\text { White Clay Creek } \\
\text { near Newark, Del. }\end{array}$ & 89.1 & $\begin{array}{l}55.9 / 0.63 \\
(1966)\end{array}$ & $\begin{array}{l}60.8 / 0.68 \\
(1965)\end{array}$ & $\begin{array}{l}60.9 / 0.68 \\
(1995)\end{array}$ & $\begin{array}{l}61.9 / 0.69 \\
(1932)\end{array}$ & $\begin{array}{l}64.7 / 0.73 \\
(1969)\end{array}$ & $\begin{array}{l}98.6 / 1.11 \\
\text { Rank }=24\end{array}$ \\
\hline 9 & 01480000 & $\begin{array}{l}\text { Red Clay Creek at } \\
\text { Wooddale, Del. }\end{array}$ & 47.0 & $\begin{array}{l}32.3 / 0.69 \\
(1995)\end{array}$ & $\begin{array}{c}32.3 / 0.69 \\
(1981)\end{array}$ & $\begin{array}{l}34.4 / 0.73 \\
(1966)\end{array}$ & $\begin{array}{c}36.3 / 0.77 \\
(1992)\end{array}$ & $\begin{array}{l}38.9 / 0.83 \\
(1965)\end{array}$ & $\begin{array}{l}51.3 / 1.09 \\
\text { Rank }=21\end{array}$ \\
\hline
\end{tabular}


The severity of the 1998-99 drought can be assessed by comparing observed streamflows with streamflows during droughts of known severity and with certain statistical measures of streamflow. Various comparisons for the index gaging stations are presented in the figures and tables that follow.

Figure 4 shows a station-by-station comparison of daily mean discharge during water year 1999 with daily mean discharge recorded during the water year of minimum annual mean discharge. Although daily mean discharges generally were greater during water year 1999, discharges from late December 1998 to early January 1999 and during part or all of the period from July to mid-September 1999 generally were less than the corresponding discharges during the water year of record low annual mean discharge.

The hydrographs in figure 5 present a comparison of daily mean discharge during water year 1999 with minimum and median daily mean discharges for the index gaging stations. The minimum daily mean discharge is the smallest mean value of discharge for a specific date, computed for this report using data for the period beginning with the first complete water year of record and ending with water year 1998 . The median daily mean discharge is the middle value of the arrayed (that is, arranged in increasing order) discharge data for a specific date, such that one-half of the values are less than the median value and one-half are greater than this value.

Inspection of hydrographs of daily mean discharge during water year 1999 and minimum and median daily mean discharge for the abbreviated periods of record reveals two basic patterns of streamflow during the water year: (1) a pattern in which the daily mean discharges generally fell within the region bounded by the graphs of minimum and daily median discharge; and (2) a pattern in which the daily mean discharges, particularly during December 1998 and late summer 1999, converged upon and dropped below the long-term minimum daily mean discharges. Water year 1999 hydrographs for the four index gaging stations in New York show patterns of the first type while hydrographs for the five stations in Pennsylvania, New Jersey, and Delaware show patterns of the second type. The differences in patterns of low streamflows result mainly from differences in the geologic environments of the drainage basins, and to a lesser extent, areal variations in precipitation. Deposits of alluvium and glacial outwash, common in major stream valleys of the northern Delaware River Basin, can store very large volumes of water. The gradual release of this water to stream channels and other surface-water features helped to moderate flows in local streams and to maintain baseflows during the drought period at relatively higher levels.

Figure 6 shows monthly mean discharges for Flat Brook near Flatbrookville, N.J., for the 1999 water year, three previous drought years, and the period of record prior to water year 1999. At this gaging station, annual mean discharge was the lowest of record during the 1965 water year, the third lowest of record during the 1985 water year, and the fourth lowest of record during the 1932 water year. Annual mean discharge during the 1999 water year was the fifth lowest of record (table 2). Flows during the fall months in all of these years were unusually low. In water year 1999, new record minimum discharges were recorded during December, July, and August. Annual mean discharges for the water years immediately preceding these four drought years do not show a consistent relation to mean discharge during the drought year. For example, water years 1932 and 1965 followed water years in which mean discharge was 72 and 65 percent, respectively, of long-term annual mean discharge. In contrast, water years 1985 and 1999 followed water years in which mean discharge was 137 and 109 percent of long-term annual mean discharge.

In addition to comparison of hydrographs, the distribution of streamflow can be compared through the use of boxplots. Boxplots are graphical displays that summarize the distribution of a data set. More importantly, boxplots can be used to compare selected statistical attributes of several data sets. These attributes are:

1. The middle value of the data set (the medianthe center line of the box)

2. The variation or spread (the inter-quartile range - the height of the box)

3. The skewness (the quartile skew-the relative size of box halves) 

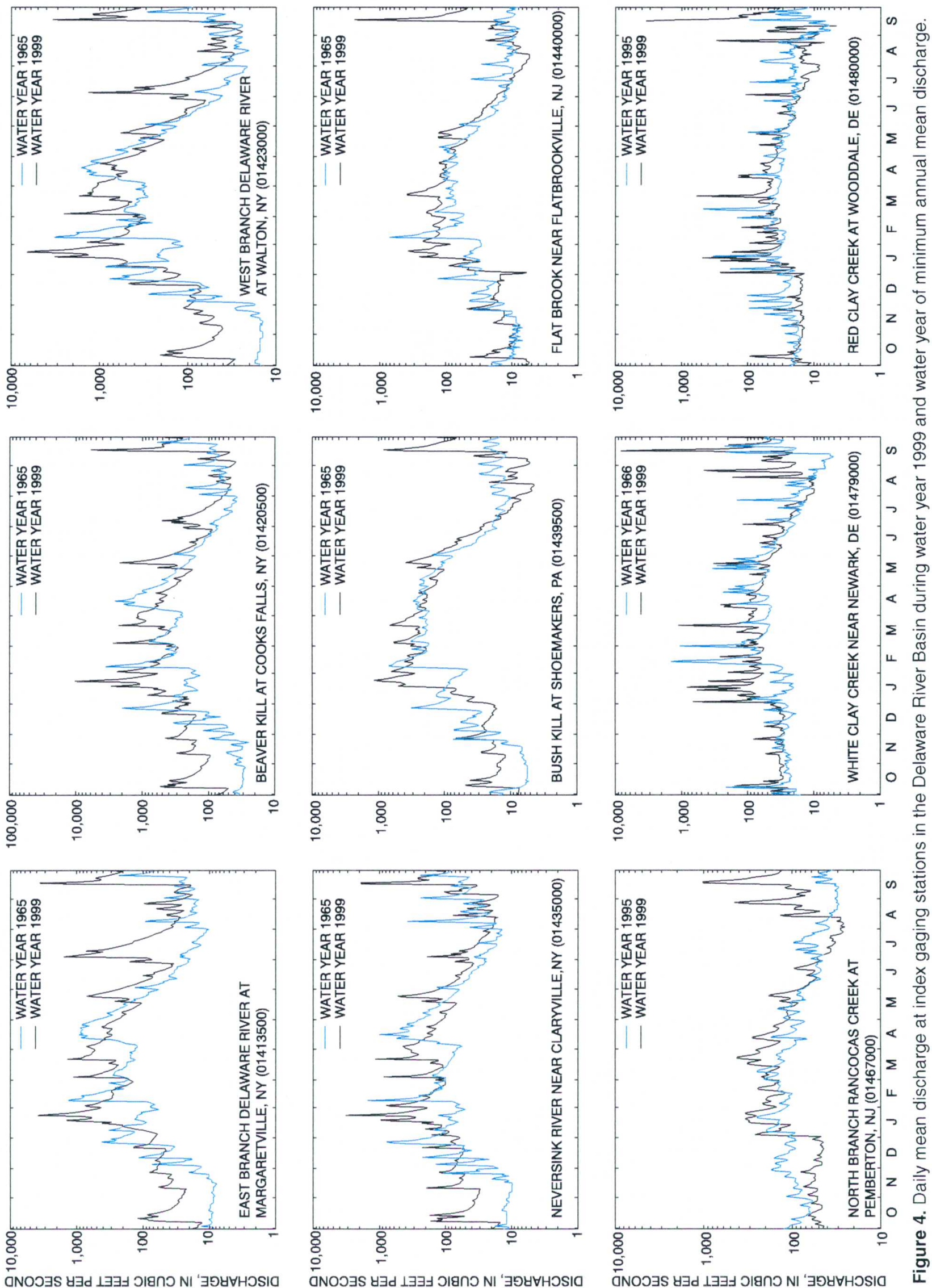

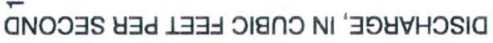

ฮNOJ 


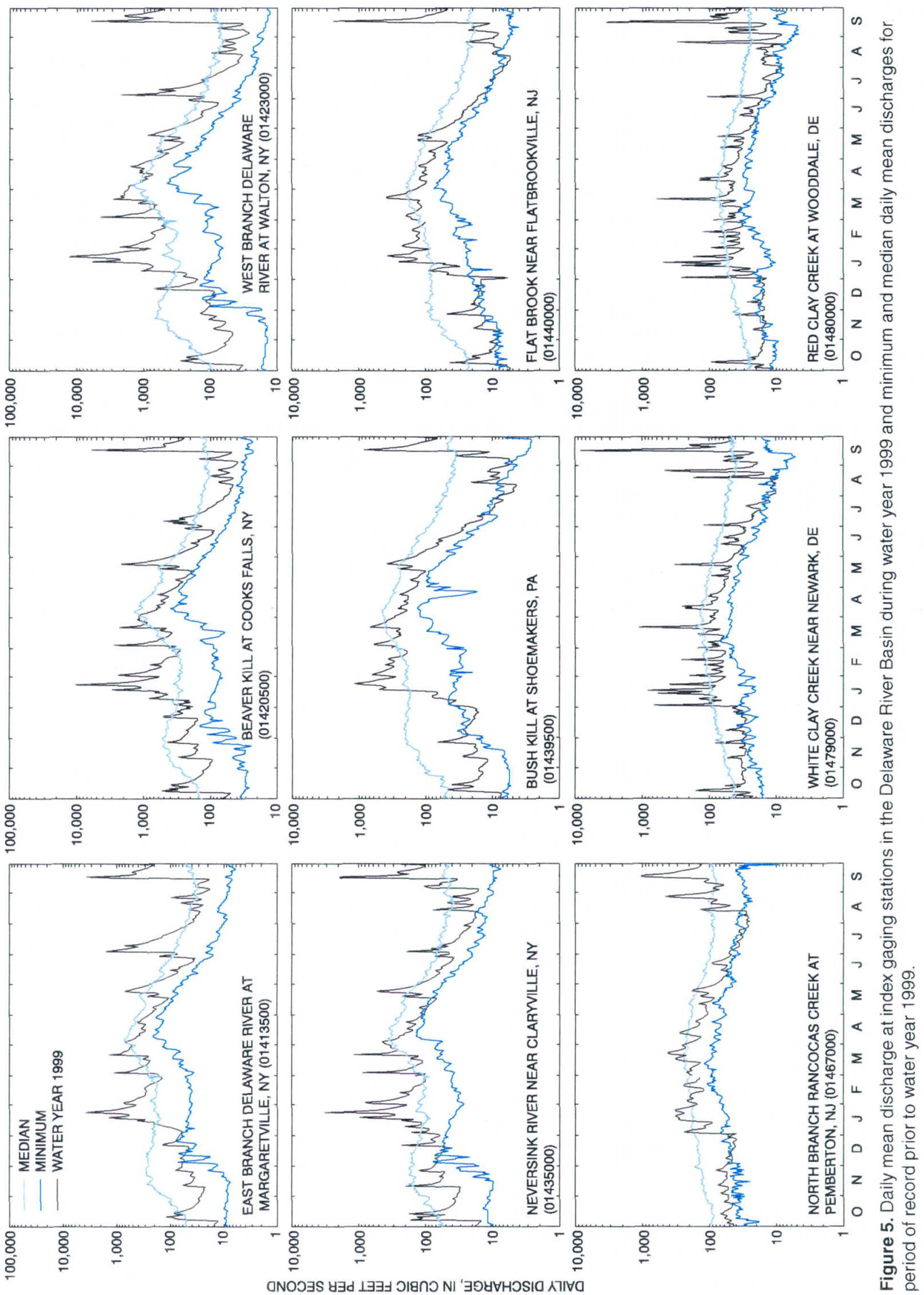




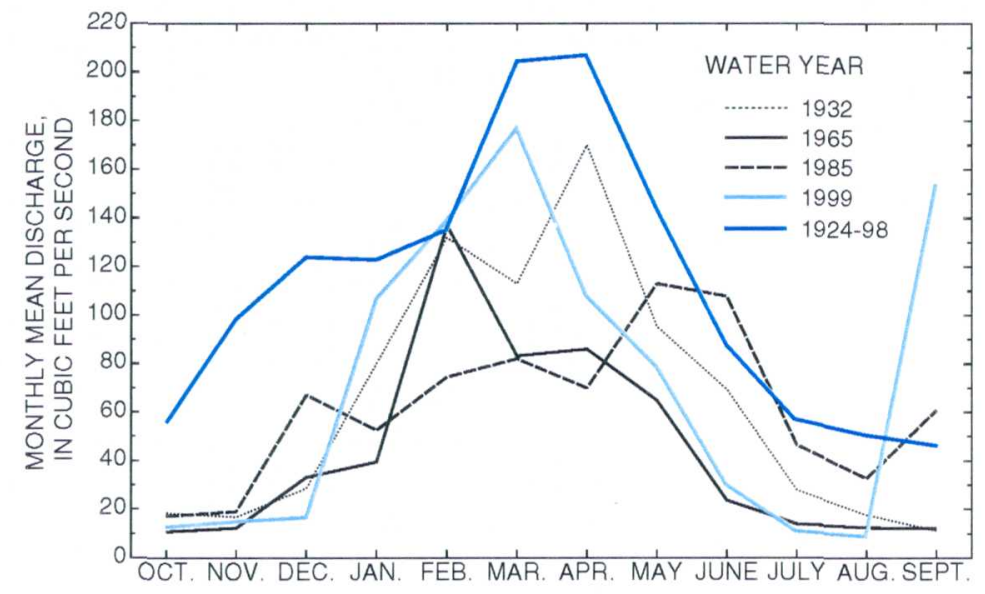

Figure 6. Monthly mean discharge for four selected drought years and period of record prior to water year 1999, Flat Brook near Flatbrookville, N.J.

4. The presence or absence of unusual values (the outlying values).

Figure 7 shows the features of a (sample) standard boxplot. In this example and this report section, the data sets under consideration consist of values of discharge. Later, boxplots are used to depict distributions of ground-water levels.

In this report, because the focus is on low streamflows, the "whisker" above the box has been shortened to extend only to the last observation within one step beyond the end of the box. A step is equivalent to 1.5 times the height-or interquartile range - of the box. Values of discharge greater than 1 step above the box are intentionally not shown on the boxplots for the index gaging stations.

Boxplots of discharge for the index gaging stations are presented in figure 8 . The boxplots illustrate the distribution of streamflows during water year 1999, the water year of lowest annual mean streamflow, and the period of record prior to water year 1999. A common characteristic of the boxplots is the longer upper box halves and whiskers, which indicate a typical, right-skewed distribution of the streamflow data.

Inspection of boxplots for the index-station data sets reveals two basic distributions of low streamflow: (1) a distribution in which the mini- mum, 25th percentile, and median values of discharge during water year 1999 are measurably greater than the corresponding values for the water year of lowest annual mean streamflow; and (2) a distribution in which the minimum, 25th percentile, and median values of discharge during water year 1999 are approximately equal to the corresponding values for the water year of lowest annual mean streamflow. Distributions of the first type are indicated for the four index gaging stations in New York whereas distributions of the second type are indicated for the five stations in Pennsylvania, New Jersey, and Delaware. As noted previously, differences in the distributions of low streamflows are primarily a result of differences in the geologic environments of the drainage basins.

Overall, the boxplots show that the distributions of low streamflows during water year 1999 in the Pennsylvania, New Jersey, and Delaware parts of the Delaware River Basin strongly resembled the distributions observed during the water years of lowest annual mean streamflows. In contrast, except for flows in the Neversink River near Claryville, water year 1999 streamflows in the New York part of the basin, although under stress, did not recede to levels approaching the record low levels measured during the drought of the 1960's.

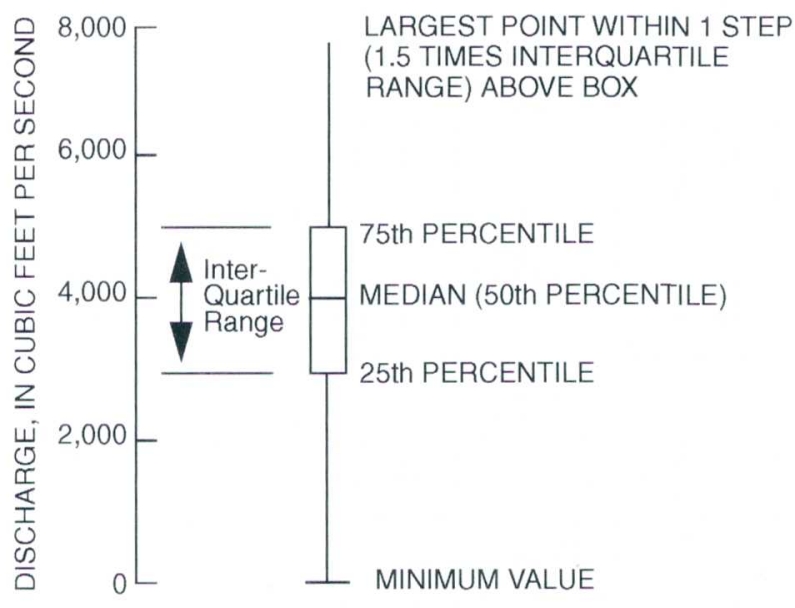

Figure 7. Features of a standard boxplot. 

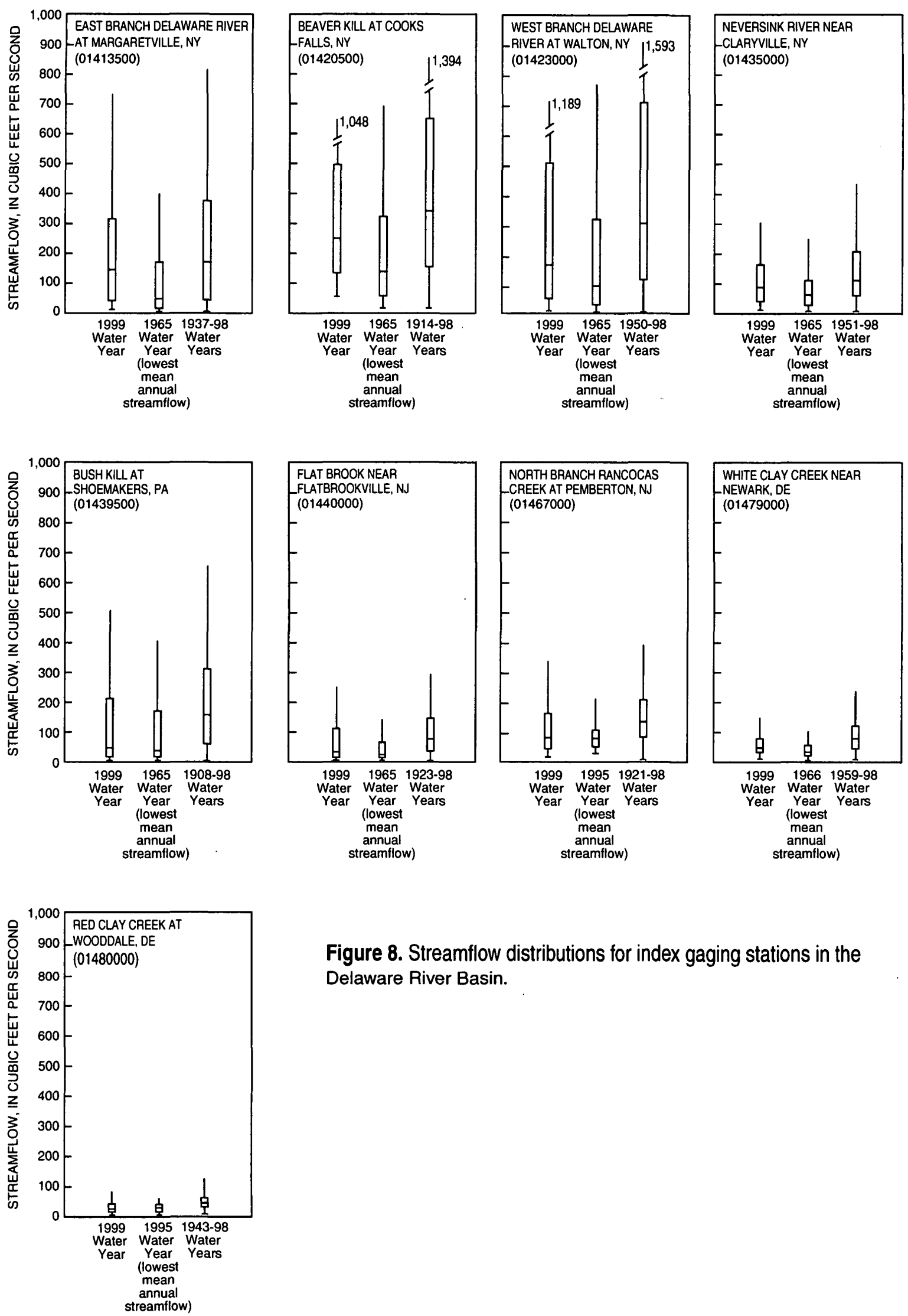

Figure 8. Streamflow distributions for index gaging stations in the Delaware River Basin. 
Trends in streamflow during most of 1998 and 1999 at the index gaging stations are shown in figure 9. The graphs depict accumulated departures from normal streamflow by month. A downward-sloping line during any period indicates deficient flow in that period. The 13-to-17 month overall periods extend from the first month of deficient streamflow in spring or summer 1998 to September 1999, when streamflow surpluses resulting from Tropical Storm Floyd were recorded at all the stations. The lowest point on each graph represents the maximum streamflow deficiency. For 8 of the 9 stations, the maximum deficiency was in August 1999.

The accumulated deficiencies are equivalent to the normal streamflow for periods ranging from 0.28 to 0.55 years. The shortest periods are for streams in the New York part of the basin, where flows were supported at moderate levels by greater ground-water inflow, precipitation, and some snowmelt. The longest period is for the Red Clay Creek at Wooddale, Del., where streamflow was deficient in all months from April 1998 to August 1999. Because they begin at arbitrary points in time, the graphs in figure 9 should not be interpreted to mean that the total monthly accumulated departures from normal streamflow must rise to zero deficiency before streamflows in these basins return to normal.

An alternative tool for evaluating low-streamflow data is the flow-duration curve, which shows the percentage of time during which specified discharges were equaled or exceeded in a given time period. Flow-duration curves for three index gaging stations, constructed on the basis of daily-mean discharge values, are shown in figure 10. These stations are in the upper, middle, and lower parts of the Delaware River Basin. For each station, three curves are shown-one for water year 1999, one for the water year of lowest mean annual flow, and one for the period of record beginning with the first complete water year of record and ending with water year 1998. Curves for individual water years represent the distributions of streamflow in specific one-year periods whereas curves for the abbreviated periods of record represent long-term average distributions of flow during the periods. The flow-duration curves are presented to illustrate how streamflow during water year 1999 compares with record-low and long-term average flow frequencies at representative gaging stations, and how low-flow characteristics differ with location. The flow-duration curves have not been normalized on the basis of drainage area or average flow and therefore, direct comparison of curves between stations is not appropriate. Also, because the data used to generate the curves are not necessarily statistically independent, estimates of return periods for low-flow events have not been made directly from the curves.

The distribution of low streamflows during water year 1999 at Beaver Kill at Cooks Falls, N.Y. (fig. 10A) - an upper basin stream-resembles the long-term average distribution of low flows during water years 1913-98. The flow-duration curve for water year 1999 has the same general shape as the curve for water year 1965-the water year of minimum annual mean flow-although flows during water year 1965, for equivalent values of frequency, are considerably smaller than flows during water year 1999. The low-streamflow distribution during water year 1999 at Bush Kill at Shoemakers, Pa. (fig. 10B)—a middle basin stream-closely resembles the distribution during water year 1965. The flow-duration curve for water year 1999 differs significantly from the curve for the 1908-98 reference period. At some levels of frequency, streamflows during water year 1999 were smaller than the corresponding flows during water year 1965. The duration curve of low streamflows during water year 1999 for White Clay Creek near Newark, Del. (fig. 10C)-a lower basin stream-lies approximately midway between the curves for water year 1966 and water years 1932-98. However, water-supply withdrawals by the City of Newark, upstream of this gaging station, have a definite but unknown effect on low-flow frequency. Further, withdrawals were discontinued for 56 days between June 29 and September 14, 1999 because of extremely low streamflows (Talley, 2000). These perturbations of low streamflow need to be considered when interpreting the low-flow frequency characteristics for water year 1999.

Table 3 presents summary data on low streamflows during the abbreviated periods of record and water year 1999. Also tabulated is the 7-day, 10-year low-flow statistic $(\mathrm{Q} 7,10)$, which is the 

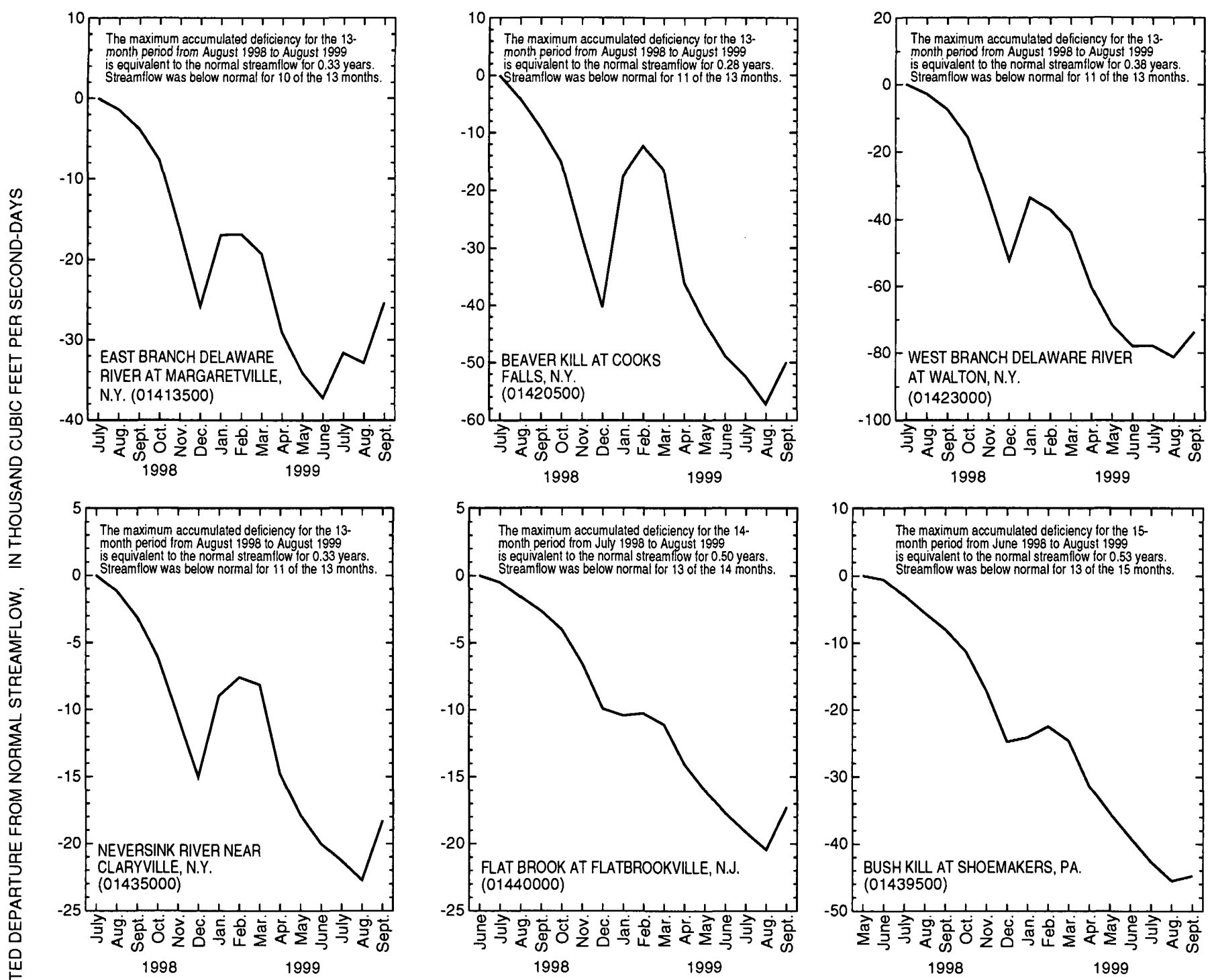

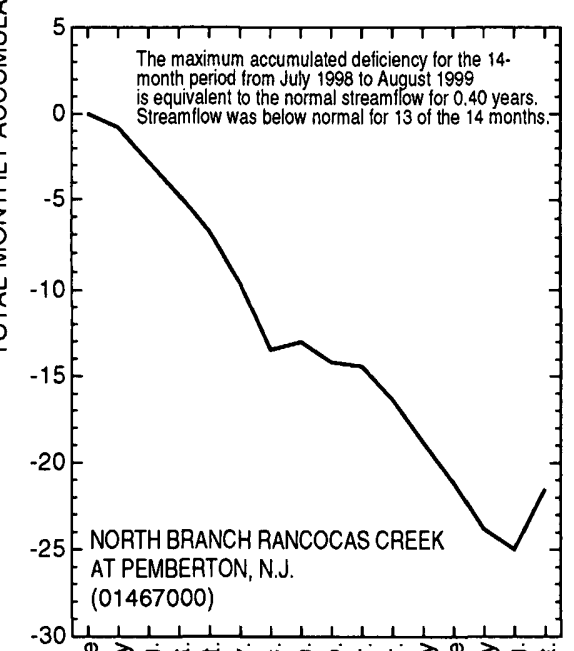

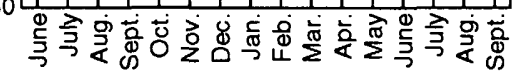
1998

1999

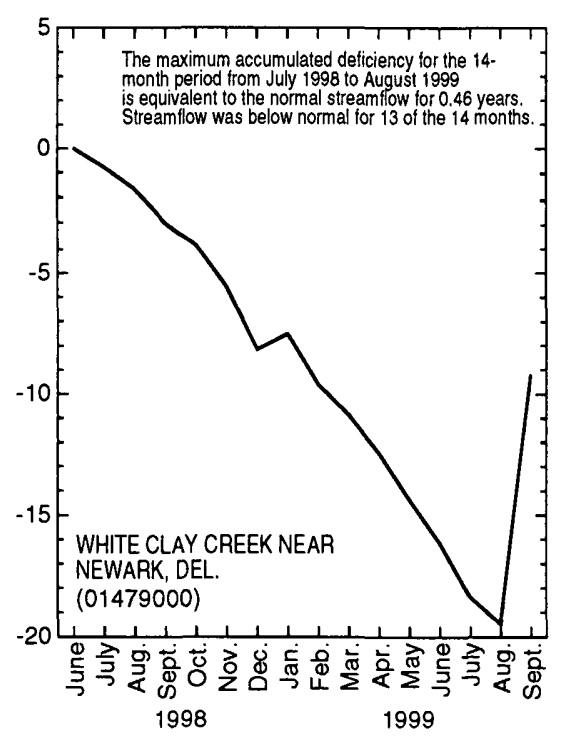

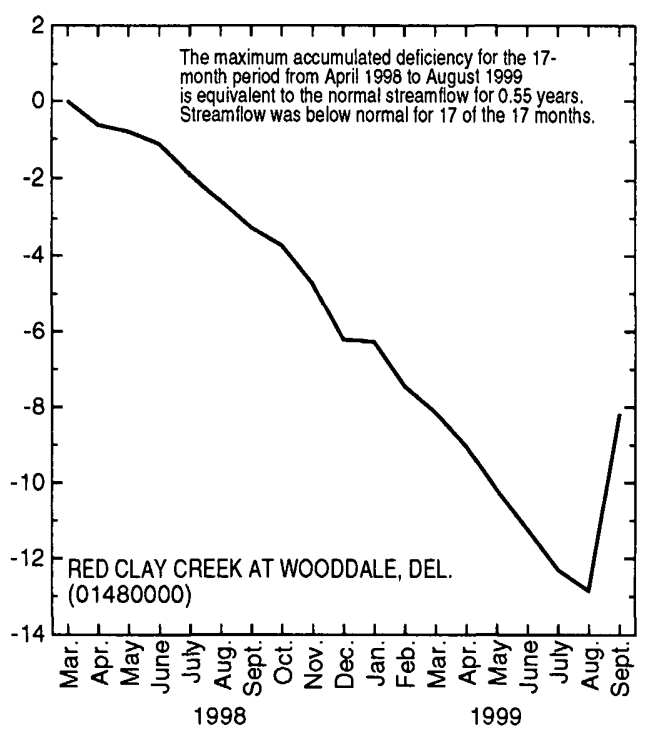

Figure 9. Streamflow trends at index gaging stations in the Delaware River Basin. 

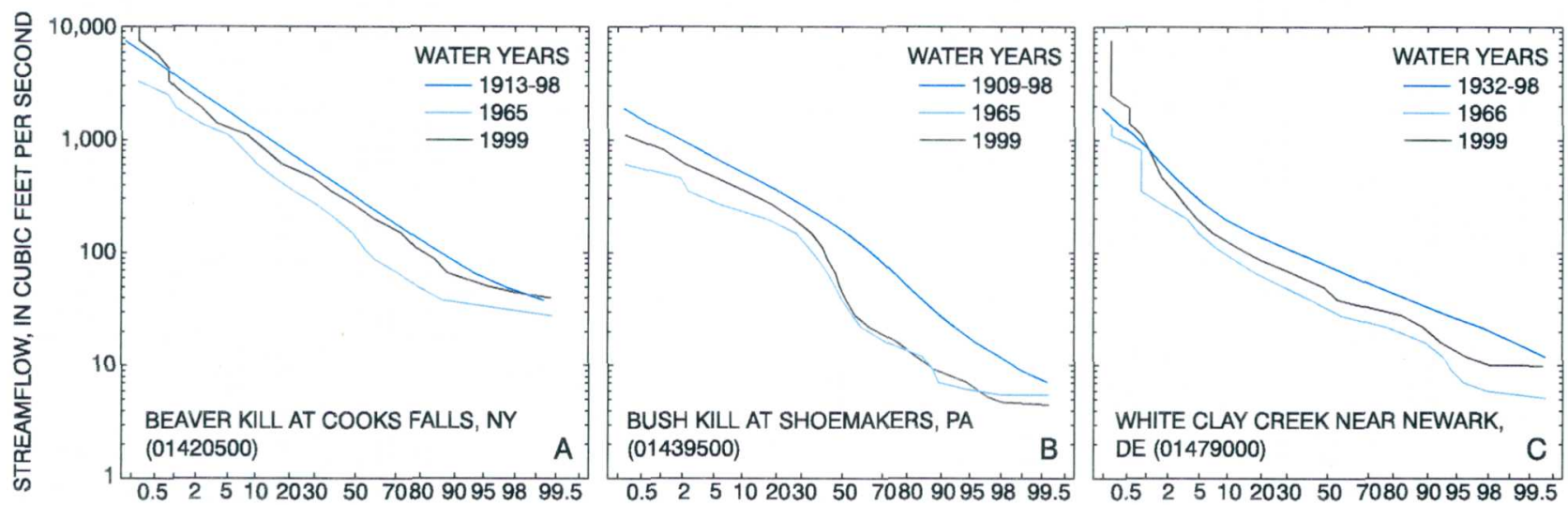

Figure 10. Flow-duration curves for three selected index gaging stations in the Delaware River Basin.

average minimum streamflow that can be expected for 7 consecutive days once every 10 years. This statistic commonly is used by regulatory agencies to determine assimilation capacities and permissible waste-loading rates for streams. During water year 1999, minimum daily mean flows at the four index gaging stations in New York came close to, but did not fall below, the respective Q7,10 flows. In contrast, minimum daily mean flows at the index stations in Pennsylvania, New Jersey, and Delaware were less than the Q7,10 flows on one or more days during the water year.

Despite their value in comparing streamflow distributions for various periods, flow-duration curves do not reveal the sequence of low flows or indicate whether the low flows occurred consecutively over several weeks or were distributed more uniformly throughout the year. The analysis of flow duration can be made more useful, however, by determining the flows over a given period of consecutive days. The results of such an analysis are presented in table 4, which gives summary data on annual n-day minimum mean streamflows during the 1998-99 drought and the period of record 1, 7, 30,60 , and 90-consecutive day minimum mean flows for the index gaging stations.

Streamflow conditions at USGS streamflowgaging stations before and after the passage of Tropical Storm Floyd on September 16, 1999, are illustrated on the maps in figure 11. These maps were obtained from the USGS Real-Time Water Data website at http://water.usgs.gov/realtime.html.
The symbols represent discharge as a percentile, which is computed from the historical record for each date shown. Only stations with at least 30 years of record are used in the computation. On September 14, streamflows were deficient, with most flows in the less than 10th percentile and the 10th - 25th percentile ranges (fig. 11A). By September 17, drought effects on streamflows were virtually eliminated, as runoff from heavy rain caused most flows to surge to record high levels (fig. 11B).

\section{Reservoir Storage}

Several large reservoirs have been constructed in the upper and lower parts of the Delaware River Basin. Three water-supply reservoirs in the upper basin-Pepacton, Cannonsville, and Neversinkare owned and operated by the City of New York. With a combined capacity of nearly $271 \mathrm{Bgal}$, these reservoirs account for about 75 percent of available reservoir storage in the basin. Water from these reservoirs is diverted to New York City and northern New Jersey for public supply and released into the Delaware and Neversink Rivers to maintain legally stipulated streamflows at the USGS gaging station at Montague, N.J.(fig. 1). The remaining 25 percent of storage is split about evenly between hydropower reservoirs in the upper part of the basin and four reservoirs in the lower part. The hydropower reservoirs are Lake Wallenpaupack in Pennsylvania and the Mongaup River system in New York. The lower basin reservoirs-Francis E. Walter, Beltzville, Blue Marsh, and Nockamixon-are in Pennsylvania and can be used to augment flows in the Lehigh, Schuylkill, and Delaware Rivers (fig. 1). 


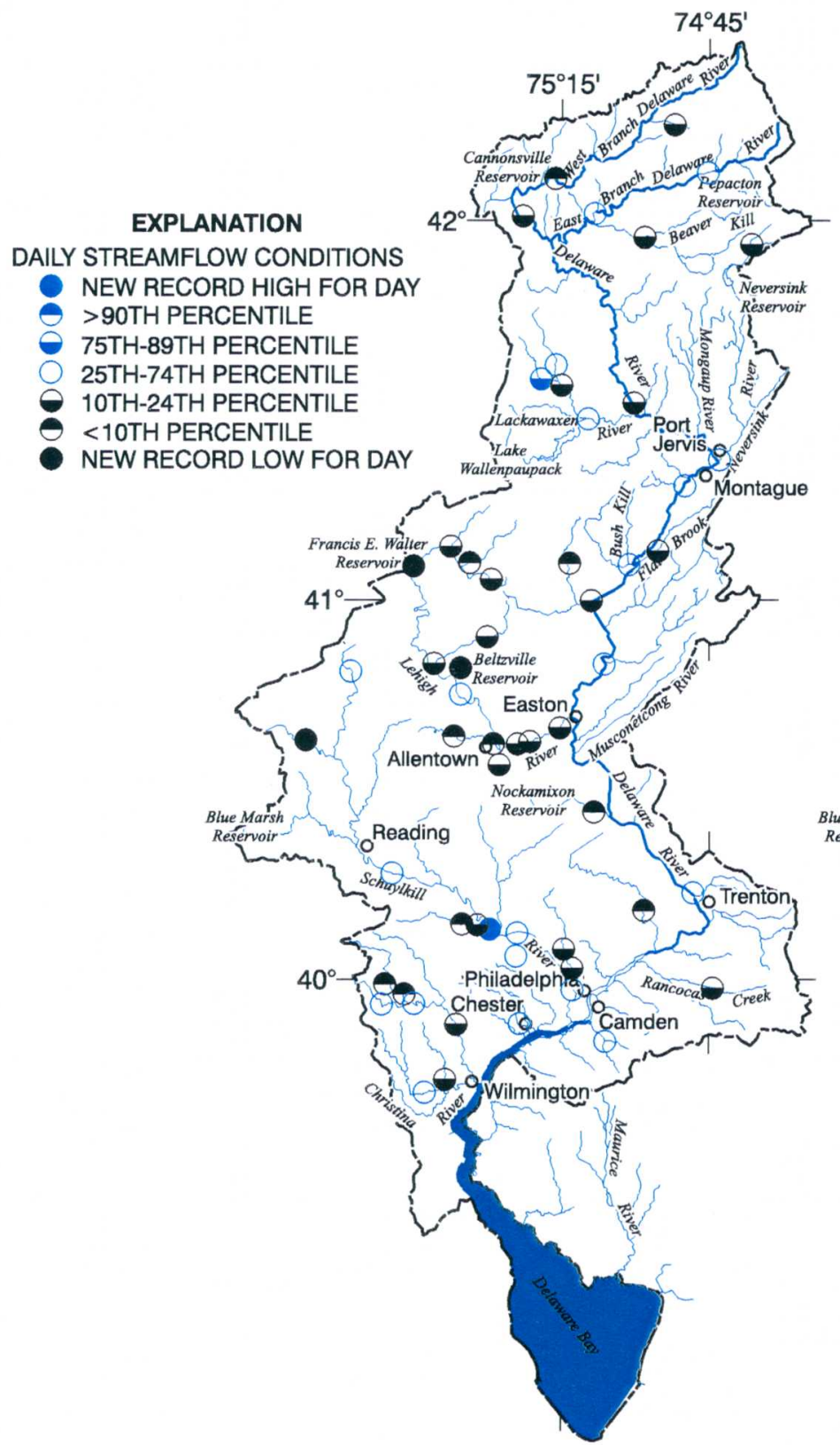

A - September 14, 1999

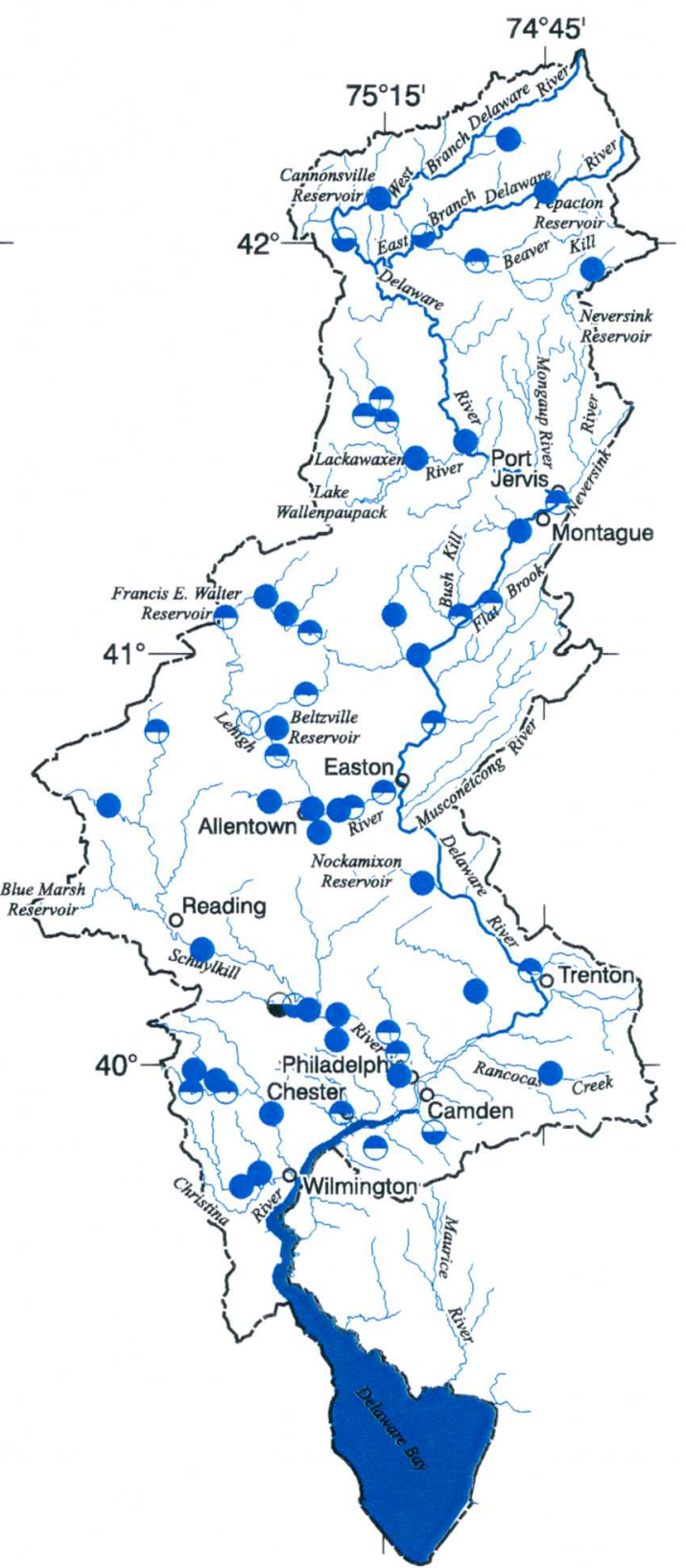

B - September 17, 1999

Figure 11. Streamflow conditions in the Delaware River Basin before and after Tropical Storm Floyd. 
Table 3. Summary data on low streamflows during period of record prior to water year 1999 and water year 1999 for index gaging stations in the Delaware River Basin

$\left[\mathrm{ft}^{3} / \mathrm{s}\right.$, cubic feet per second; low-flow statistic computed from Log-Pearson distribution of streamflow data]

\begin{tabular}{|c|c|c|c|c|c|c|c|c|c|c|c|}
\hline \multirow[b]{2}{*}{$\begin{array}{l}\text { Site } \\
\text { number on } \\
\text { figure } 1\end{array}$} & \multirow[b]{2}{*}{$\begin{array}{l}\text { USGS } \\
\text { station } \\
\text { number }\end{array}$} & \multirow[b]{2}{*}{ Station name } & \multirow[b]{2}{*}{$\begin{array}{l}\text { Drainage } \\
\text { area } \\
\text { (square } \\
\text { miles) }\end{array}$} & \multirow[b]{2}{*}{$\begin{array}{l}\text { Period of } \\
\text { record }\end{array}$} & \multicolumn{4}{|c|}{ Period of Record Prior to Water Year 1999} & \multicolumn{3}{|c|}{ Water Year 1999} \\
\hline & & & & & $\begin{array}{l}\text { Minimum } \\
\text { daily } \\
\text { mean flow } \\
\left(\mathrm{ft}^{3} / \mathrm{s}\right) \text { and } \\
\text { date }\end{array}$ & $\begin{array}{l}\text { Minimum } \\
\text { annual } \\
\text { mean flow, } \\
\left(\mathrm{ft}^{3} / \mathrm{s}\right) \text { and } \\
\text { water year }\end{array}$ & $\begin{array}{c}90 \\
\text { percent } \\
\text { of flows } \\
\text { exceed } \\
\left(\mathrm{ft}^{3} / \mathrm{s}\right)\end{array}$ & $\begin{array}{c}\text { 7-day, } \\
\text { 10-year } \\
\text { low-flow } \\
\text { statistic } \\
\left(f^{3} / s\right)\end{array}$ & $\begin{array}{l}\text { Minimum daily } \\
\text { mean flow } \\
\left(\mathrm{ft}^{3} / \mathrm{s}\right) \text { and } \\
\text { date }\end{array}$ & $\begin{array}{l}\text { Annual } \\
\text { mean } \\
\text { flow } \\
\left(\mathrm{ft}^{3} / \mathrm{s}\right)\end{array}$ & $\begin{array}{c}90 \\
\text { percent } \\
\text { of flows } \\
\text { exceed } \\
\left(\mathrm{ft}^{3} / \mathrm{s}\right)\end{array}$ \\
\hline 1 & 01413500 & $\begin{array}{c}\text { East Branch Delaware } \\
\text { River at Margaretville, } \\
\text { N.Y. }\end{array}$ & 163 & $\begin{array}{l}\text { Feb. } 1937 \text { to } \\
\text { current year }\end{array}$ & $\begin{array}{c}6.0 \\
09 / 25 / 64\end{array}$ & $\begin{array}{l}138 \\
1965\end{array}$ & 29 & 10 & $\begin{array}{c}13 ; \\
10 / 6-7 / 98\end{array}$ & 249 & 29 \\
\hline 2 & 01420500 & $\begin{array}{c}\text { Beaver Kill at } \\
\text { Cooks Falls, N.Y. }\end{array}$ & 241 & $\begin{array}{l}\text { July } 1913 \text { to } \\
\text { current year }\end{array}$ & $\begin{array}{c}23 ; \\
09 / 14 / 13\end{array}$ & $\begin{array}{l}277 \\
1965\end{array}$ & 84 & 36 & $\begin{array}{c}39 ; \\
09 / 5 / 99\end{array}$ & 446 & 60 \\
\hline 3 & 01423000 & $\begin{array}{l}\text { West Branch Delaware } \\
\text { River at Walton, N.Y. }\end{array}$ & 332 & $\begin{array}{l}\text { Oct. } 1950 \text { to } \\
\text { current year }\end{array}$ & $\begin{array}{c}13 ; \\
09 / 24 / 64\end{array}$ & $\begin{array}{l}263 ; \\
1965\end{array}$ & 56 & 22 & $\begin{array}{c}24 ; \\
09 / 5 / 99\end{array}$ & 409 & 40 \\
\hline 4 & 01435000 & $\begin{array}{l}\text { Neversink River near } \\
\text { Claryville, N.Y. }\end{array}$ & 66.6 & $\begin{array}{l}\text { July } 1951 \text { to } \\
\text { current year }\end{array}$ & $\begin{array}{c}7.5 \\
09 / 25 / 64\end{array}$ & $\begin{array}{l}100 \\
1965\end{array}$ & 32 & 12 & $\begin{array}{c}15 ; \\
10 / 6-7 / 98\end{array}$ & 147 & 24 \\
\hline 5 & 01439500 & $\begin{array}{c}\text { Bush Kill at } \\
\text { Shoemakers, Pa. }\end{array}$ & 117 & $\begin{array}{l}\text { Oct. } 1908 \text { to } \\
\text { current year }\end{array}$ & $\begin{array}{c}2.6 ; \\
09 / 25 / 64\end{array}$ & $\begin{array}{l}95.4 \\
1965\end{array}$ & 27 & 7.2 & $\begin{array}{c}4.4 \\
08 / 12 / 99\end{array}$ & 135 & 8.2 \\
\hline 6 & 01440000 & $\begin{array}{l}\text { Flat Brook near } \\
\text { Flatbrookville, N.J. }\end{array}$ & 64.0 & $\begin{array}{l}\text { July } 1923 \text { to } \\
\text { current year }\end{array}$ & $\begin{array}{c}4.1 ; \\
09 / 11 / 66\end{array}$ & $\begin{array}{l}43.4 ; \\
1965\end{array}$ & 17 & 7.5 & $\begin{array}{c}5.5 \\
10 / 3-4 / 98 \& \\
08 / 9-13 / 99\end{array}$ & 71 & 8.3 \\
\hline 7 & 01467000 & $\begin{array}{l}\text { North Branch Rancocas } \\
\text { Creek at Pemberton, N.J. }\end{array}$ & 118 & $\begin{array}{l}\text { Sept. } 1921 \text { to } \\
\text { current year }\end{array}$ & $\begin{array}{c}9.0 \\
09 / 29 / 32\end{array}$ & $\begin{array}{l}92.3 ; \\
1995\end{array}$ & 62 & 36 & $\begin{array}{c}25 ; \\
08 / 3 / 99\end{array}$ & 125 & 39 \\
\hline 8 & 01479000 & $\begin{array}{l}\text { White Clay Creek near } \\
\text { Newark, Del. }\end{array}$ & 89.1 & $\begin{array}{l}\text { Oct. } 1931 \text { to } \\
\text { Sept. 1936; } \\
\text { June } 1943 \text { to } \\
\text { Sept. } 1957 \text {; } \\
\text { Oct. } 1959 \text { to } \\
\text { current year }\end{array}$ & $\begin{array}{c}5.0 \\
09 / 10 / 66\end{array}$ & $\begin{array}{l}55.9 \\
1966\end{array}$ & 33 & 15 & $\begin{array}{c}9.3 \\
08 / 19 / 99\end{array}$ & 98.6 & 20 \\
\hline 9 & 01480000 & $\begin{array}{l}\text { Red Clay Creek } \\
\text { at Wooddale, Del. }\end{array}$ & 47.0 & $\begin{array}{l}\text { Apr. } 1943 \text { to } \\
\text { current year }\end{array}$ & $\begin{array}{c}4.5 ; \\
09 / 4 / 66\end{array}$ & $\begin{array}{l}32.3 ; \\
1995\end{array}$ & 19 & 9.9 & $\begin{array}{c}7.0 ; \\
08 / 25 / 99\end{array}$ & 50.1 & 14 \\
\hline
\end{tabular}

On June 1, 1998, the three upper Delaware River Basin water-supply reservoirs were spilling (fig. 12). Beginning in July 1998, below-normal precipitation coupled with normal diversions to New York City and New Jersey and releases to meet the streamflow objective at Montague caused storage to decrease rapidly. By December 31, 1998 , the combined capacity of the reservoirs had decreased to $99 \mathrm{Bgal}$, or about 37 percent of total capacity. The declining trend continued until January 9,1999 , when the combined contents stood at $97 \mathrm{Bgal}$, or 36 percent of capacity.

Above-normal precipitation, mainly during early to mid-January 1999, caused the storage situation to improve considerably and, by January 31 , combined reservoir storage was slightly more than $162 \mathrm{Bgal}$, or 60 percent of total capacity. Storage in the New York City reservoirs in the Delaware River Basin increased steadily during the late-winter to spring refill period. By late April 1999, the combined contents reached a seasonal high of about $250 \mathrm{Bgal}$, or $21 \mathrm{Bgal}$ less than full capacity, and remained around that level during May. Unlike 1998, the reservoirs did not spill at any time during 1999 . The seasonal pattern of decline began in early June, and during June and early July, the rate of decline was moderate. Later in July, as a result of decreasing inflows and increasing releases, diversions, and evapotranspiration, combined storage began to decrease precipitously, and, on several dates in early August, the rate of depletion exceeded 2 Bgal per day. During September 9-15, immediately preceding Tropical Storm Floyd, combined storage decreased at about 1.3 Bgal/d, and, on September 15, reached a level of $133 \mathrm{Bgal}$, or 49 percent of total capacity.

Drenching rains in the upper Delaware River Basin, delivered by Tropical Storm Floyd on September 16, resulted in a very rapid increase in inflow to Pepacton, Cannonsville, and Neversink reservoirs. During the 3-day period immediately 
Table 4. Summary data on annual n-day minimum streamflows during the 1998-99 drought and record low $\mathrm{n}$-consecutive day values at index gaging stations in the Delaware River Basin

$\left[\mathrm{ft}^{3} / \mathrm{s}\right.$, cubic feet per second]

\begin{tabular}{|c|c|c|c|c|c|c|c|c|c|c|c|c|c|c|}
\hline \multirow[t]{2}{*}{$\begin{array}{l}\text { Site number } \\
\text { on } \\
\text { figure } 1\end{array}$} & \multirow[t]{2}{*}{$\begin{array}{l}\text { USGS } \\
\text { station } \\
\text { number }\end{array}$} & \multirow[t]{2}{*}{ Station name } & \multirow[t]{2}{*}{$\begin{array}{l}\text { Drainage } \\
\text { area } \\
\text { (square } \\
\text { miles) }\end{array}$} & \multirow[t]{2}{*}{$\begin{array}{l}\text { Period of } \\
\text { record }\end{array}$} & \multicolumn{5}{|c|}{$\begin{array}{c}\text { Minimum mean flow }\left(\mathrm{ft}^{3} / \mathrm{s}\right) \text { from } \\
\text { April } 1,1998 \text { to September } 30 \\
1999, \text { for indicated number of } \\
\text { consecutive days }\end{array}$} & \multicolumn{5}{|c|}{$\begin{array}{l}\text { Minimum mean flow }\left(\mathrm{ft}^{3} / \mathrm{s}\right) \text { for } \\
\text { period of record for indicated } \\
\text { number of consecutive days }\end{array}$} \\
\hline & & & & & 1 & 7 & 30 & 60 & 90 & 1 & 7 & 30 & 60 & 90 \\
\hline 1 & 01413500 & $\begin{array}{c}\text { East Branch Delaware } \\
\text { River at Margaretville, } \\
\text { N.Y. }\end{array}$ & 163 & $\begin{array}{l}\text { Feb. } 1937 \text { to } \\
\text { current year }\end{array}$ & 13 & 15 & 20 & 24 & 31 & 6.0 & 6.8 & 8.3 & 8.6 & 8.9 \\
\hline 2 & 01420500 & $\begin{array}{c}\text { Beaver Kill at } \\
\text { Cooks Falls, N.Y. }\end{array}$ & 241 & $\begin{array}{l}\text { July } 1913 \text { to } \\
\text { current year }\end{array}$ & 39 & 43 & 57 & 66 & 104 & 23 & 26 & 30 & 31 & 33 \\
\hline 3 & 01423000 & $\begin{array}{l}\text { West Branch Delaware } \\
\text { River at Walton, N.Y. }\end{array}$ & 332 & $\begin{array}{l}\text { Oct. } 1950 \text { to } \\
\text { current year }\end{array}$ & 24 & 27 & 39 & 45 & 57 & 13 & 13 & 15 & 15 & 16 \\
\hline 4 & 01435000 & $\begin{array}{c}\text { Neversink River near } \\
\text { Claryville, N.Y. }\end{array}$ & 66.6 & $\begin{array}{l}\text { July } 1951 \text { to } \\
\text { current year }\end{array}$ & 15 & 17 & 20 & 25 & 37 & 7.5 & 8.9 & 10 & 11 & 12 \\
\hline 5 & 01439500 & $\begin{array}{c}\text { Bush Kill at } \\
\text { Shoemakers, Pa. }\end{array}$ & 117 & $\begin{array}{l}\text { Oct. } 1908 \text { to } \\
\text { current year }\end{array}$ & 4.4 & 4.7 & 7.6 & 8.5 & 15 & 2.6 & 2.7 & 4.0 & 6.0 & 6.1 \\
\hline 6 & 01440000 & $\begin{array}{c}\text { Flat Brook near } \\
\text { Flatbrookville, N.J. }\end{array}$ & 64.0 & $\begin{array}{l}\text { July } 1923 \text { to } \\
\text { current year }\end{array}$ & 5.5 & 5.6 & 7.3 & 9.2 & 12 & 4.1 & 5.3 & 6.0 & 8.4 & 8.7 \\
\hline 7 & 01467000 & $\begin{array}{l}\text { North Branch Rancocas } \\
\text { Creek at Pemberton, N.J. }\end{array}$ & 118 & $\begin{array}{l}\text { Sept. } 1921 \text { to } \\
\text { current year }\end{array}$ & 25 & 27 & 30 & 42 & 53 & 9.0 & 27 & 31 & 36 & 41 \\
\hline 8 & 01479000 & $\begin{array}{l}\text { White Clay Creek near } \\
\text { Newark, Del. }\end{array}$ & 89.1 & $\begin{array}{l}\text { Oct. } 1931 \text { to } \\
\text { Sept. 1936; } \\
\text { June } 1943 \text { to } \\
\text { Sept. } 1957 \text {; } \\
\text { Oct. } 1959 \text { to } \\
\text { current year }\end{array}$ & 9.3 & 10 & 13 & 22 & 29 & 5.0 & 5.7 & 9.0 & 16 & 17 \\
\hline 9 & 01480000 & $\begin{array}{l}\text { Red Clay Creek } \\
\text { at Wooddale, Del. }\end{array}$ & 47.0 & $\begin{array}{l}\text { Apr. } 1943 \text { to } \\
\text { current year }\end{array}$ & 7.0 & 8.6 & 12 & 16 & 18 & 4.5 & 4.9 & 6.8 & 9.5 & 12 \\
\hline
\end{tabular}

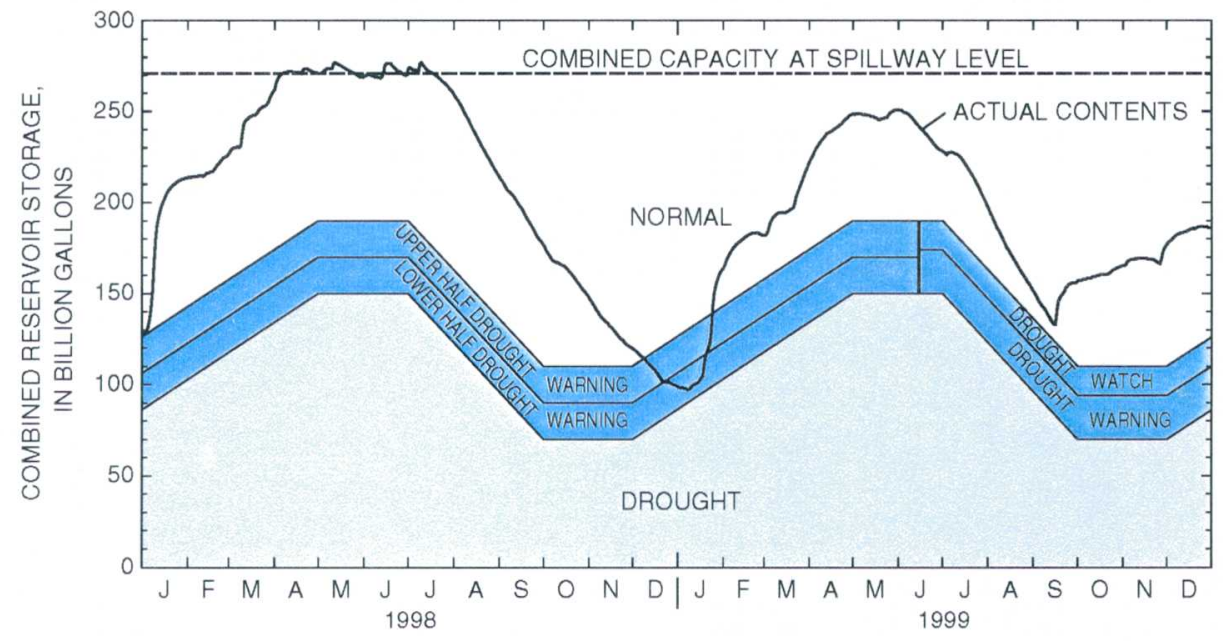

Figure 12. Actual contents and operating curves for New York City reservoirs in the Delaware River Basin, January 1, 1998, to December 31, 1999. 
after the storm, the combined contents increased by nearly 15 Bgal. Subsequently, storage in the reservoirs increased steadily through December 31, 1999, when the combined contents stood at about $186 \mathrm{Bgal}$ (fig. 12). Table 5 presents a monthly summary of total, median, and minimum combined storage for the New York City Delaware River Basin reservoirs.

The impact of the 1998-99 drought on upper basin reservoir storage can be gauged by comparing observed storage with storage during previous notable droughts. The drought of 1984-85 in the Delaware River Basin was selected for this comparison, because it had major adverse effects on storage in the three New York City reservoirs in the upper basin. The following description of this earlier episode is modified from Harkness and others (1986).

From August 1984 to April 1995, precipitation in the upper Delaware River Basin was below normal. This deficiency resulted in well-below-normal streamflow for all months of this period except December. During the critical reservoir-filling months of November through May, streamflow was about 55 percent of normal. From late May to August, the upper basin received near-normal precipitation. During this period, however, streamflow remained below normal, except in July, when normal flows prevailed. The return to normal streamflow conditions was delayed because much of the precipitation in May and June contributed to easing the soil-moisture deficiency in the basin. By September 1985, streamflow conditions were well below normal. At the end of September, Hurricane Gloria and a frontal system moving through the area combined to provide about 5 in. of precipitation, resulting in above-average precipitation and streamflow for the month. The hydrologic effects of this precipitation event carried over into October.

Figure 13 shows the effects of this precipitation (and consequently, streamflow) deficiency on the New York City reservoirs in the Delaware River Basin. From June to late-November 1985, combined storage declined continually and rapidly, reaching a level of about $110 \mathrm{Bgal}$, or 41 percent of total capacity. From January 1985 to late September 1985, storage remained at relatively low levels ranging from about $118 \mathrm{Bgal}$ (44 percent of capacity) in February to about $167 \mathrm{Bgal}$ (62 percent of capacity) in June. Heavy rain in late September 1985 and above-normal precipitation in November 1985 resulted in substantial increases in reservoir storage, and, by late December 1985, combined storage stood at $200 \mathrm{Bgal}$, or about 74 percent of capacity.

Comparison of upper basin reservoir storage during these two drought episodes shows that while storage was under stress during the 1998-99 drought, particularly during summer 1999 , low-storage conditions during 1984-85 were far more severe and persistent. Although the 1998-99 drought had a significant effect on reservoir storage, the impact was not as great as impacts on other major components of the hydrologic system.

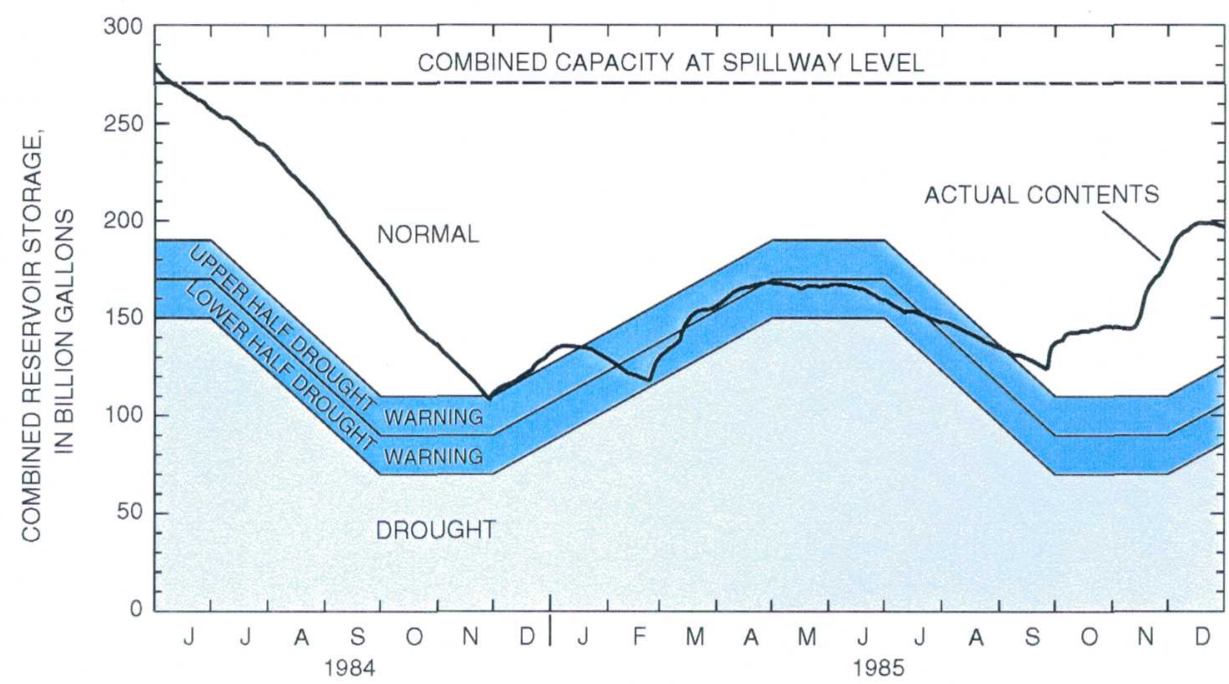

Figure 13. Actual contents and operating curves for New York City reservoirs in the Delaware River Basin, June 1, 1984, to December 31, 1985. 
Table 5. Summary data on combined storage for New York City reservoirs in the Delaware River Basin, June 1998 - December 1999

[Storage reported in millions of gallons; actual, median, and minimum storage are for first day of month]

\begin{tabular}{cccccc}
\hline Date & $\begin{array}{c}\text { Combined storage } \\
\text { for Pepacton, } \\
\text { Cannonsville, } \\
\text { and Neversink } \\
\text { Reservoirs }\end{array}$ & $\begin{array}{c}\text { Percentage of total } \\
\text { combined storage }\end{array}$ & $\begin{array}{c}\text { Median combined } \\
\text { storage for } \\
\text { period of record }\end{array}$ & $\begin{array}{c}\text { Percentage of } \\
\text { median } \\
\text { storage }\end{array}$ & $\begin{array}{c}\text { Minimum combined } \\
\text { storage for } \\
\text { period of record }\end{array}$ \\
\hline 1998 & & & & & \\
June & 269,471 & 99 & 269,782 & 100 & 166,807 \\
July & 273,336 & 101 & 256,975 & 106 & 159,464 \\
Aug. & 259,382 & 96 & 230,241 & 113 & 148,255 \\
Sept. & 214,193 & 79 & 201,946 & 106 & 134,868 \\
Oct. & 176,843 & 65 & 179,533 & 99 & 98,488 \\
Nov. & 147,984 & 55 & 145,485 & 102 & 94,027 \\
Dec. & 119,682 & 44 & 166,770 & 72 & 84,721 \\
1999 & & & & & \\
\hline Jan. & 98,925 & 37 & 189,563 & 52 & 88,645 \\
Feb. & 163,562 & 60 & 214,266 & 76 & 68,566 \\
Mar. & 181,890 & 67 & 220,839 & 82 & 129,370 \\
Apr. & 221,935 & 82 & 259,789 & 85 & 147,865 \\
May & 248,634 & 92 & 271,282 & 92 & 168,082 \\
June & 250,711 & 93 & 269,782 & 93 & 166,807 \\
July & 228,163 & 84 & 256,975 & 89 & 159,464 \\
Aug. & 197,366 & 73 & 230,241 & 86 & 148,255 \\
Sept. & 151,275 & 56 & 201,946 & 75 & 134,868 \\
Oct. & 156,677 & 58 & 179,533 & 87 & 98,488 \\
Nov. & 165,217 & 61 & 145,485 & 114 & 94,027 \\
Dec. & 177,092 & 65 & 166,770 & 106 & 84,721 \\
\hline
\end{tabular}

In summer 1999, supplemental releases of water from Beltzville, Blue Marsh, and Francis E. Walter Reservoirs were directed by the Delaware River Basin Commission, in order to meet flow objectives for the Delaware River at Trenton, N.J. and to control the upstream migration of brackish water in the Delaware estuary. Flow-augmentation releases were made from June 28 to September 15, and total directed-release quantities are as follows: 2.5 Bgal from Beltzville Reservoir; 2.0 Bgal from Blue Marsh Reservoir; and 0.61 Bgal from Francis E. Walter Reservoir. In addition to the directed releases, conservation releases totaling about $8 \mathrm{Bgal}$ were made from these reservoirs for flow-augmentation and habitat-protection purposes.

\section{Ground-Water Occurrence and Levels}

Ground water in the Delaware River Basin is stored in, and moves through, water-bearing sedi- ments and rocks called aquifers. The dry-weather flow of most streams in the basin is sustained by ground-water discharge (baseflow) from aquifers. Where aquifers with large capacity to store and transmit water are present, baseflow is sustained even through prolonged dry periods; where aquifers with limited capacity to store and transmit water are present, baseflow decreases fairly rapidly and may eventually cease, causing streams to dry up during rainless periods.

Ground-water levels are an important barometer of the state of ground-water systems and are used by many water-management agencies as a primary indicator of drought conditions. Fluctuations of ground-water levels are caused by imbalances in recharge to and discharge from the systems. In natural ground-water systems, the recharge-discharge regimen produces an annual cycle of fluctuations in which water levels typically are highest in spring and lowest in fall. Information 
on ground-water levels and fluctuations is needed to evaluate the status of ground-water supplies and to detect any changes or trends in those supplies. In this report, the term "ground-water level" refers to the depth to the water table or potentiometric surface, in feet $(\mathrm{ft})$ below the land surface.

The USGS, in cooperation with various state and local agencies, operates continuing programs of observation-well networks in the Delaware River Basin. These networks are designed to monitor fluctuations of ground-water levels, which are controlled by geologic, climatic, and hydrologic factors, and by human activities. The networks provide basic information on how water levels respond to rainfall, ground-water pumping, and other stresses. Because of the relatively large number and long record length of USGS observation wells in the Pennsylvania part of the basin, water-level data for those wells are used in this report as the basis for evaluating the impact of the 1998-99 drought on ground-water systems. Figure 14 shows the location of these wells.

\section{Drought Effects on Ground-Water Levels}

The 1998-99 drought in the Delaware River Basin had a major effect on ground-water levels. In fact, many members of the water-resources community referred to this drought as a "ground-water drought." Although ground-water supplies generally were not deficient, the combination of below-normal recharge and elevated rates of evapotranspiration produced abnormal water-level declines and record or near-record low ground-water levels in much of the basin.

In the discussion and illustrations that follow, "normal" status signifies a mean water level between the 25th percentile and the 75th percentile of monthly mean water levels for all prior years of record for the month indicated. "Below normal" status signifies a mean water level less than the 25th percentile of historical monthly mean water levels. "Above normal" status signifies a mean water level greater than the 75th percentile of historical monthly mean water levels.
During the drought period, ground-water conditions elsewhere in the basin were generally similar to those in the Pennsylvania part. The general pattern of change in ground-water levels was one of decline from May to December 1998, and much less than the usual recovery in winter. Consequently, ground-water levels were below normal after winter 1998-99 and at the beginning of the 1999 growing season, and they declined steadily through summer 1999. In the Pennsylvania part of the basin, many new record monthly low levels were set in USGS network observation wells during 1999. In early January 1999, the lowest water levels of record, regardless of month, were measured in observation wells in Bucks and Schuylkill Counties. In early September 1.999, the lowest water level of record was measured in a network well in Berks County. Water levels in these three wells have been measured continuously since 1975. Water levels in several other observation wells came very close to, but did not decline below, the lowest water levels of record (table 6). In neighboring Delaware, the lack of recharge resulted in near-record low ground-water levels throughout the state (Talley, 2000).

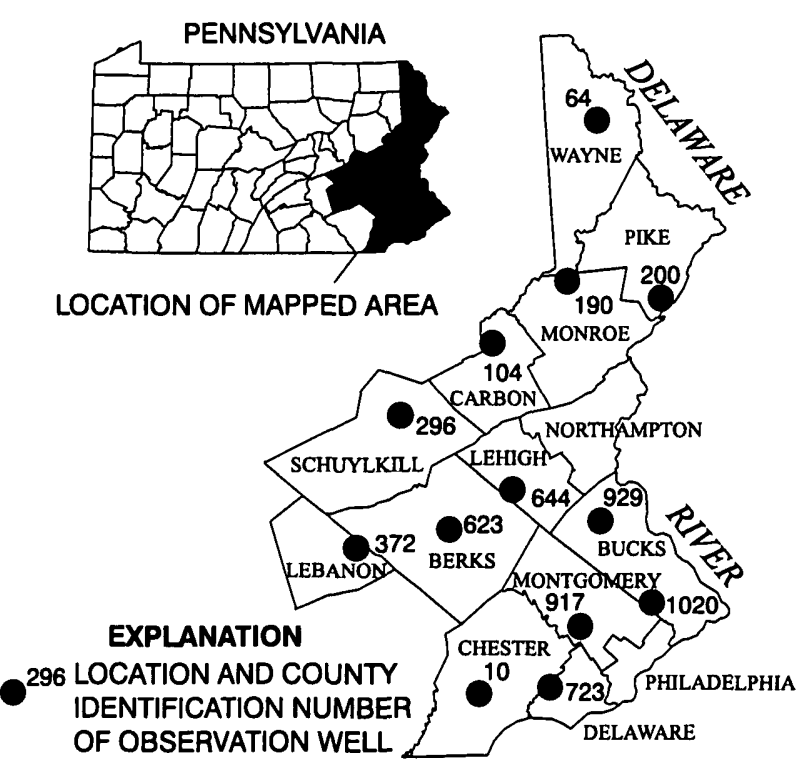

Figure 14. Location of selected observation wells operated by the U.S. Geological Survey in the Pennsylvania part of the Delaware River Basin. 
The hydrographs in figure 15 show water levels during 1995-99 in three USGS observation wells in the Pennsylvania part of the Delaware River Basin. For each well, the observed water levels are compared with the average of daily low water levels in the well during the period of continuous record prior to 1995. Hydrographs for 1995-97 are included to illustrate antecedent conditions. During the period January 1998 to December 1999, water levels in the Monroe County and Chester County wells were below the long-term average low for 12 of 24 months. In contrast, water levels in the Berks County well were below the long-term average low for 21 of 24 months. Even during the 1998-99 winter-to-spring recovery period and after the passage of Tropical Storm Floyd in mid-September 1999, water levels in the Berks County well did not rise above the long-term average low level.

The severity of the 1998-99 drought can be assessed by comparing observed ground-water levels with water levels measured during droughts of known severity. The 1961-67 event was the most severe drought ever recorded in the Delaware River Basin. Thus, ground-water levels measured during this historical episode provide a reference frame against which the effects of the 1998-99 drought can be measured. Water-level records for USGS observation well $\mathrm{CH}-10$ in Chester County, Pennsylvania were selected for comparison because records for this well date back to 1951 and water levels have been relatively unaffected by human activities during the entire period of record.

Hydrographs of water levels for observation well CH-10 for 1961-63 and 1997-99 are shown in figure 16 . These periods were selected as the timeframes for the comparison because they include the intervals when ground-water levels declined to their lowest points during each drought. Hydrographs of water levels during 1963 and 1999 -- the years with the greatest declines -- are aligned on a common time scale to facilitate comparison of the lowest water levels during each drought.

In 1963, ground-water levels began the seasonal cycle of decline in March, decreased to a record low level of $16.22 \mathrm{ft}$ below land surface in November 1963, and did not begin to recover substantially until January 1964. Water levels remained at about $16 \mathrm{ft}$ below land surface during all of August, September, and October. In 1999, ground-water levels also began the seasonal cycle of decline in March, although water levels at the beginning of this cycle were about $2 \mathrm{ft}$ higher than the corresponding levels in 1963. The decline continued steadily until September 1999 and was followed by a rapid recovery because of recharge from Tropical Storm Floyd. Water levels remained at their lowest point $-15.27 \mathrm{ft}$ below land surface-for 2 days in August 1999. In addition to these differences in lowest water levels, ground-water levels remained at very low levels for

Table 6. Comparison of record low ground-water levels with low levels during the 1998-99 drought

[Water levels reported in feet below land surface; well locations shown on figure 14]

\begin{tabular}{lllclcl}
\hline $\begin{array}{c}\text { Pennsylvania } \\
\text { county }\end{array}$ & $\begin{array}{c}\text { USGS } \\
\text { well } \\
\text { number }\end{array}$ & $\begin{array}{c}\text { Year } \\
\text { record } \\
\text { began }\end{array}$ & $\begin{array}{c}\text { Lowest } \\
\text { water level } \\
\text { of record }\end{array}$ & $\begin{array}{c}\text { Date of } \\
\text { record low } \\
\text { water level }\end{array}$ & $\begin{array}{c}\text { Lowest water level } \\
\text { measured during } \\
\text { July 1998 to } \\
\text { December } 1999\end{array}$ & $\begin{array}{c}\text { Date of lowest } \\
\text { water level during } \\
\text { July } 1998 \text { to } \\
\text { December 1999 }\end{array}$ \\
\hline Berks & BE-623 & 1975 & 141.20 & $9 / 5 / 99$ & 141.20 & $9 / 5 / 99$ \\
Bucks & BK-1020 & 1975 & 41.68 & $1 / 2,3 / 99$ & 41.68 & $1 / 2,3 / 99$ \\
Carbon & CB-104 & 1969 & 90.58 & $1 / 31 / 81$ & 82.85 & $10 / 10 / 98$ \\
Chester & CH-10 & 1951 & 16.22 & $11 / 3 / 63$ & 15.27 & $8 / 25,26 / 99$ \\
Lebanon & LB-372 & 1973 & 11.32 & $1 / 23,30 / 81$ & 11.20 & $9 / 5 / 99$ \\
Lehigh & LE-644 & 1971 & 93.42 & $2 / 6 / 71$ & 82.84 & $9 / 5 / 99$ \\
Monroe & MO-190 & 1967 & 16.87 & $10 / 24,25 / 80$ & 16.58 & $9 / 15 / 99$ \\
Schuylkill & SC-296 & 1975 & 56.03 & $1 / 1,2 / 99$ & 56.03 & $1 / 1,2 / 99$ \\
Wayne & WN-64 & 1967 & 32.98 & $11 / 9,10,11 / 91$ & 30.26 & $9 / 14,15,16 / 99$ \\
\hline
\end{tabular}




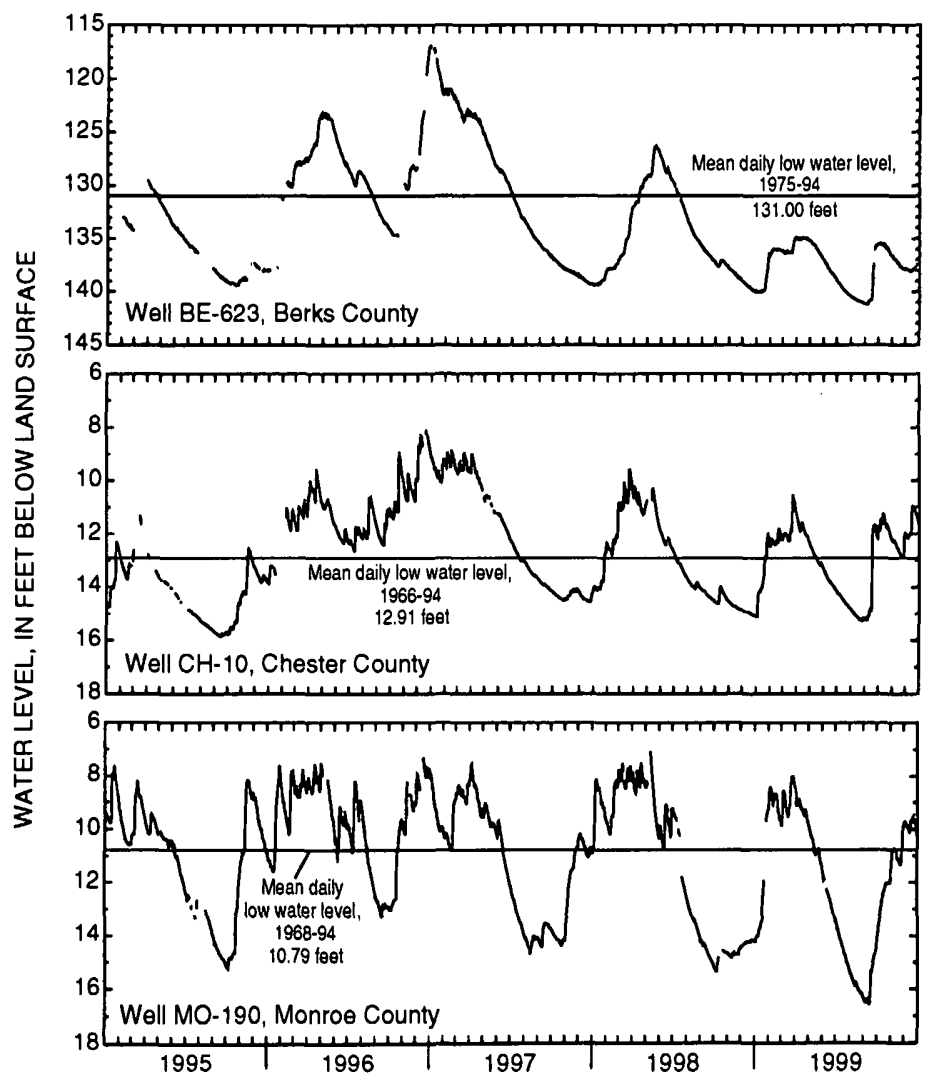

Figure 15. Ground-water levels in three observation wells in the Delaware River Basin in Pennsylvania, 1995-99.

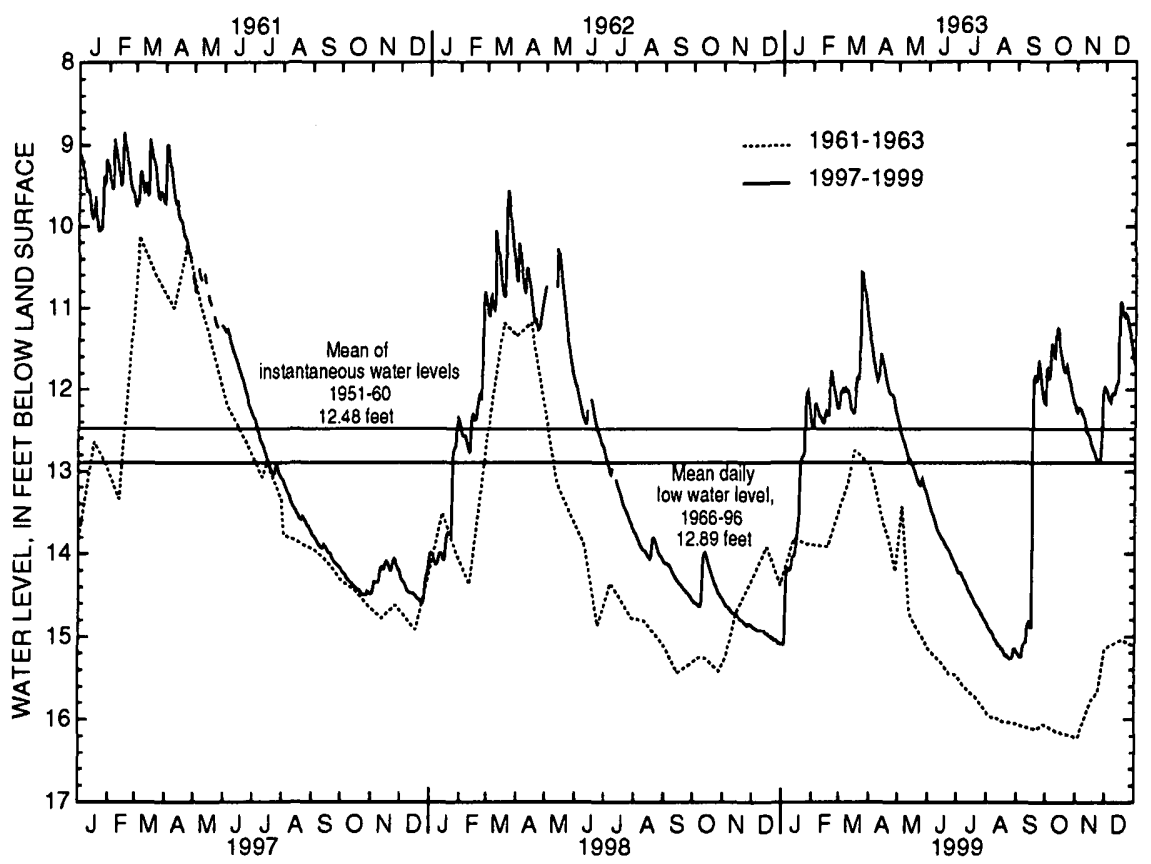

Figure 16. Ground-water levels in observation well $\mathrm{CH}-10$, Chester County, Pennsylvania, 1961-63 and 1997-99. 
a considerably longer period in 1963 than in 1999. Rates of water-level decline and recovery, however, were lower in 1963 than in 1999 (fig. 16).

Ground-water levels measured during the two droughts also can be compared through the use of boxplots. Figure 17 presents a comparison of boxplots of water levels in well CH-10 during 1963 and 1999. Fewer water-level data were used in the preparation of the boxplot for 1963 , because at that time, water levels were measured manually about two times per month. These water levels are considered instantaneous readings and do not necessarily represent the maximum (lowest) water level on the day of the measurement. In contrast, water levels were recorded on a continuous basis during 1999, and a data set consisting of daily maximum water levels was used to prepare the boxplot. Despite the differences in the number of data points, the boxplots can be used in a general way to compare ground-water levels during these two drought years.

Although ground-water levels were below normal in 1999, they did not exceed the historical low levels set in 1963. In 1963, 25 percent of all measured ground-water levels were above a level of about $14 \mathrm{ft}$; in 1999, 75 percent of ground-water levels were above $14 \mathrm{ft}$. Further, the median ground-water level for $1963-15.20 \mathrm{ft}$ - is approximately equal to the lowest level$15.27 \mathrm{ft}$-measured during all of 1999 .
In terms of ground-water effects, the drought of 1998-99 had a major impact on ground-water levels in the Delaware River Basin, but it was not as great as the impact during the drought of the 1960 's. This is not unexpected, however, as severe depletion of ground-water reservoirs, with their large storage capacity, is unlikely during droughts of relatively short duration.

The areal extent and propagation of drought effects is illustrated by the series of monthly ground-water conditions maps presented in figure 18. These maps show the status of monthly mean ground-water levels in USGS observation wells in the Pennsylvania part of the Delaware River Basin. Maps showing ground-water conditions during June and December 1998, and March, June, August, and October 1999 are presented to illustrate the general patterns of change in ground-water levels before and during the drought, and after the passage of Tropical Storm Floyd.

Monthly maps and water-level data for the period January 1997 to current month, including the months not shown on figure 18 , are available on the USGS Pennsylvania District home page at http://pa.water.usgs.gov/gw_report.

In June 1998, ground-water levels in 12 of the 13 USGS observation wells were in the normal to above-normal range. The water level in the Montgomery County observation well set a new record high for the month, although water levels in this

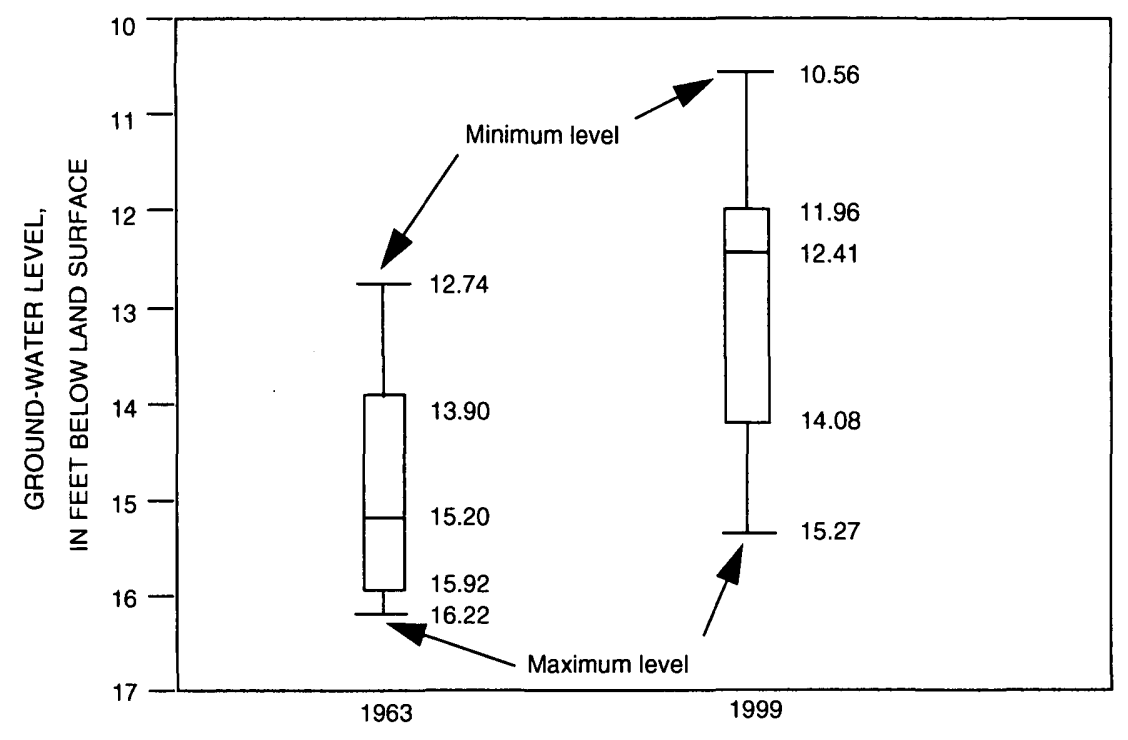

Figure 17. Distribution of ground-water levels in observation well $\mathrm{CH}-10$, Chester County, Pennsylvania, 1963 and 1999. 

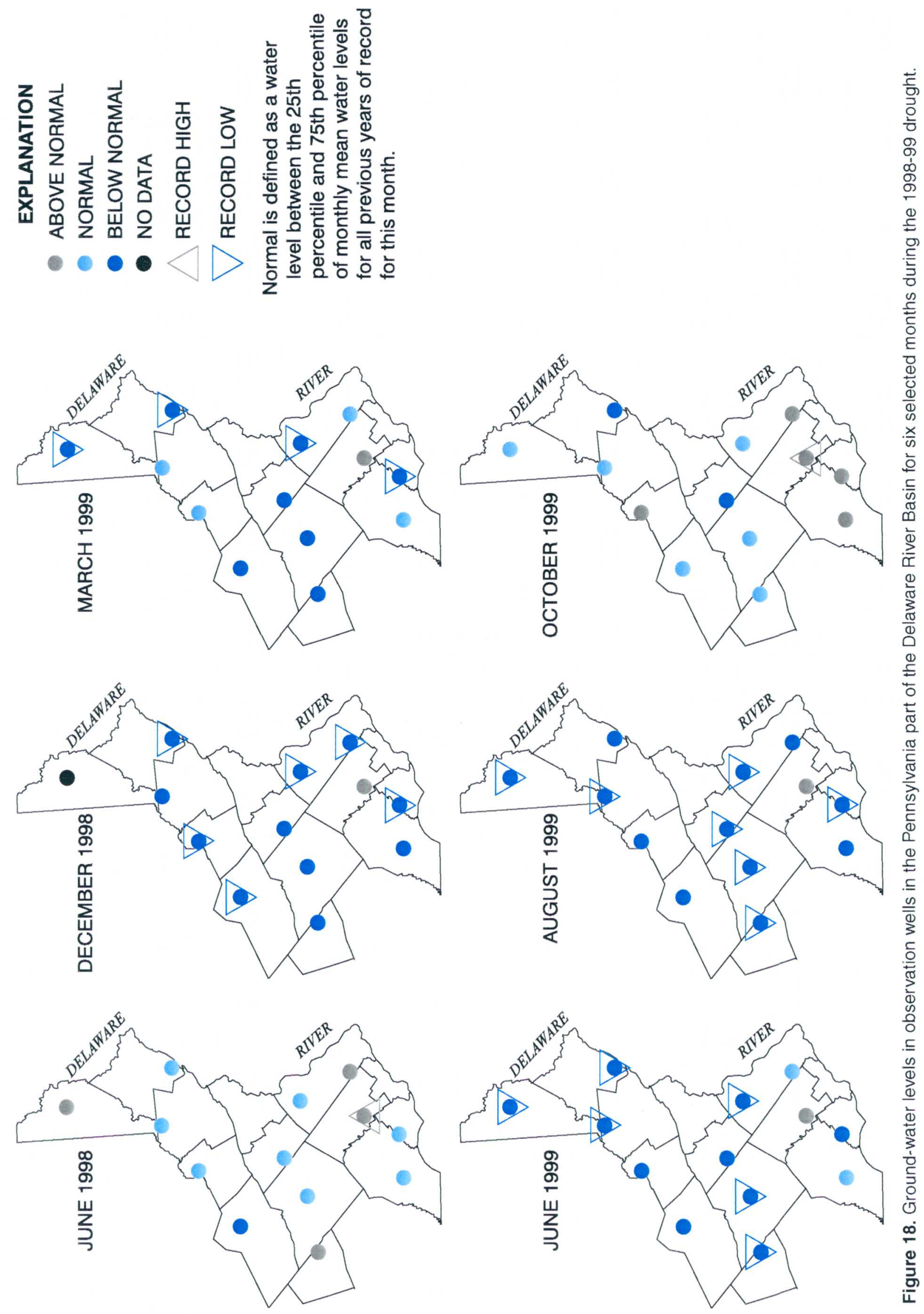
well have been rising steadily (an increasing trend) since the early 1990's in response to a reduction in ground-water pumping in the surrounding area.

The water level in the Schuylkill County well was below normal during the month.

By December 1998, the status of ground-water levels had changed dramatically, and levels in 11 observation wells were in the below-normal range. Water levels in observation wells in Bucks ( 2 wells), Carbon, Delaware, Pike, and Schuylkill Counties set new record lows for the month.

In March 1999, which roughly marked the end of the winter ground-water recharge period and the beginning of the growing season, ground-water levels were in the normal to above-normal range in 5 observation wells and in the below-normal range in 8 wells. New record monthly lows were set in wells in Bucks (1 well), Delaware, Pike, and Wayne Counties.

Ground-water levels during June 1999 reflectdeepening and spreading drought conditions. Except for normal to above-normal water levels in 3 wells in southeastern Pennsylvania, groundwater levels were below normal in the rest of the Pennsylvania part of the Delaware River Basin. Water levels in 6 observation wells-3 in northeastern Pennsylvania and 3 in southeastern Pennsylvania-set new record lows for the month.

August 1999 was the last full month of drought conditions, as rain associated with Tropical Storm Floyd arrived in the Delaware River Basin on September 16. During August, ground-water levels in 12 of 13 observation wells were in the below-normal range. The lowest ground-water levels since July 1998 were recorded in observation well CH-10 (Chester County) on August 25 and 26,1999 , and in early to mid-September in five other USGS observation wells (table 6). The lowest water levels of record in wells BK-1020 and SC-296 (Schuylkill County), regardless of month, were measured on January 2 and 3, 1999 and January 1 and 2,1999, respectively. The lowest water level of record in well BE-623 (Berks County), was measured on September 5, 1999. Records have been kept on these three wells since 1975 .

By October 1999, rain from Tropical Storm Floyd replenished soil moisture and recharged ground-water reservoirs, and ground-water levels recovered significantly from their pre-storm levels. Although below-normal water levels persisted in several areas, water levels generally were in the normal to above-normal range throughout the Delaware River Basin.

\section{INSTITUTIONAL RESPONSE TO THE 1998-99 DROUGHT}

Although this report is concerned with the hydrologic aspects of the 1998-99 drought in the Delaware River Basin, the following chronology is included to document the major institutional and management actions taken in response to the drought. 
Date, 1999

June 10

June 28

July 14

July 20

July 21

July 23

August 5

August 5

August 5

August 10

August 16

August 18

September 16, 17 Tropical Storm Floyd delivers heavy rain to the Delaware River Basin.

Pennsylvania declares a drought warning in 47 counties, including all counties in the Delaware River Basin.

Delaware River Basin Commission (DRBC) begins directing releases from lower basin reservoirs in Pennsylvania.

$D R B C$ requests use of one-half of the excess release quantity stipulated for the New York City Delaware River Basin reservoirs, to help meet the Trenton flow objective. DRBC develops the release schedule and the Delaware River Master administers the program.

Pennsylvania declares a drought emergency in 55 counties, including all counties in the Delaware River Basin.

DRBC and Parties to the 1954 Supreme Court Decree agree to reduce the Trenton flow objective to $2,700 \mathrm{ft}^{3} / \mathrm{s}$, pending subsequent approval and ratification by the DRBC Commissioners.

Delaware declares a drought warning and urges voluntary water conservation.

New Jersey declares a statewide water emergency with mandatory restrictions on non-essential outdoor water use.

Delaware declares a drought emergency for the region north of the Chesapeake and Delaware Canal.

Army Corps of Engineers begins storing additional water in Francis E. Walter Reservoir. (Primary purpose of reservoir is flood control and recreation).

New York State issues a drought warning for counties in the Delaware River Basin.

Delaware River Master informs DRBC that all available excess release quantity has been used for meeting flow needs of the lower basin.

DRBC approves Resolution 99-18, which supports the drought actions of the basin states, authorizes use of water in power reservoirs and Nockamixon Reservoir to meet [lower basin] flow objectives, and allows DRBC to request contingency plans from users in excess of $1 \mathrm{Mgal} / \mathrm{d}$ if requested by a basin state.

Source: Modified from Delaware River Basin Commission, written communication, March 31, 2000. 


\section{SUMMARY}

Unusually dry conditions prevailed in the Middle Atlantic region from July 1998 to September 1999. In the Delaware River Basin, as in other parts of the region, surface and subsurface components of the hydrologic system showed a pronounced response to the precipitation deficiency. This report documents the precipitation deficiency associated with the drought and examines hydrologic system response-namely, reductions in streamflow and reservoir storage, and declines in ground-water levels-to the shortfall.

The 1998-99 drought in the Delaware River Basin was caused by anomalous patterns in the general atmospheric circulation. Displacement of the jet stream and redirection of moisture from Gulf and Atlantic subtropical sources were major factors in diverting moisture away from the basin.

The deficient precipitation trend began in July 1998 and, with few exceptions, monthly totals were below normal until September 1999. As a result of these many shortfalls, the accumulated precipitation deficiency increased quickly. By August 1999, precipitation during the previous 12-month period in the part of the basin above Trenton, N.J. was more than 12 in. below normal. The precipitation deficiency also was reflected in below-normal snowpack during winter 1998-99. The drought was broken in mid-September 1999, when Tropical Storm Floyd delivered about 5 in. of rain to the northern part of the basin and about 10 in. to the southern part. Despite these heavy rains, 12-previous month accumulated precipitation totals remained in the deficient range for at least 7 months after the storm. Thus, future weather conditions will determine whether this storm eliminated the drought or merely interrupted a longer term episode.

Discharge records for nine index gaging stations operated by the U.S. Geological Survey were selected for analysis of drought-affected low streamflows. These stations were chosen because of their distributed location and because they generally are on unregulated or minimally regulated streams. Various visual and statistical techniques, including hydrograph and boxplot comparisons, graphs of trends, flow-duration curves, and daily streamflow-conditions maps, were used to analyze data on low streamflows. These analyses show that the 1998-99 drought in the Delaware River Basin was one of the most severe short-term droughts of the 20th century. In 1999, streamflows receded to minimum levels in late summer instead of the more typical early fall timeframe. Extreme, persistent heat in summer 1999 compounded the effects of the drought on low streamflows.

Three water-supply reservoirs in the upper Delaware River Basin, owned and operated by the City of New York, are used in-part to maintain legally stipulated flow rates in the Delaware River at Montague, N.J. These reservoirs have a combined capacity of nearly $271 \mathrm{Bgal}$ and account for about 75 percent of available reservoir storage in the basin. From July 1998 to January 1999, storage in these reservoirs declined rapidly as a result of below-normal precipitation coupled with normal diversions and releases. The minimum storage level during the drought was reached on January 9, 1999, when combined contents stood at $97 \mathrm{Bgal}$ or 36 percent of total capacity. On September 15, 1999, immediately before Tropical Storm Floyd passed over the basin, combined contents stood at $133 \mathrm{Bgal}$, or 49 percent of total capacity. On several days in early August 1999, at the height of the drought, depletion of these reservoirs exceeded $2 \mathrm{Bgal} / \mathrm{d}$.

The 1998-99 drought in the Delaware River Basin also had a major effect on ground-water levels. Below-normal recharge and elevated rates of evapotranspiration combined to produce abnormal water-level declines and record or near-record low ground-water levels in much of the basin. Records for USGS network observation wells in the Pennsylvania part of the basin were used as an indicator of drought impacts on ground-water levels. In 1999, many new record monthly low levels were reached in network wells, and the lowest water levels of record, regardless of month, were recorded in three network wells. Although ground-water levels were below normal in 1999, limited evidence suggests they did not exceed the historical low levels set in the early 1960's. By October 1999, rain from Tropical Storm Floyd replenished soil moisture and recharged ground-water reservoirs, and ground-water levels recovered significantly from their pre-storm levels. 
Although below-normal water levels persisted in several areas, water levels generally were in the normal to above-normal range throughout the Delaware River Basin.

\section{REFERENCES CITED}

Barksdale, H.C., O'Bryan, Deric, and Schneider, W.J., 1966, Effect of drought on water resources in the northeast: U.S. Geological Survey Hydrologic Atlas 243, 1 sheet.

Changnon, S.A., 1987, Detecting drought conditions in Illinois: Illinois State Water Survey Circular 164-87, 36 p.

Hare, F.K., 1987, Drought and desiccation-Twin hazards of a variable climate, in Whilhite, David, Eastering, William, and Wood, David, eds., Planning for drought: Boulder, Colo., Westview Press, p. 3-9.

Harkness, W.E., Lins, H.F., and Alley, W.M., 1986, Drought in the Delaware River Basin, 1984-85, in National Water Summary 1985-Hydrologic events and surface-water resources: U.S. Geological Survey Water-Supply Paper 2300, p. 29-34.
Klemes, V.E., 1987, Drought prediction-A hydrologic perspective, in Whilhite, David, Eastering, William, and Wood, David, eds., Planning for drought: Boulder, Colo., Westview Press, p. 81-94.

Namias, Jerome, 1985, Hydrologic aspects of drought, in Beran, M.A., and Rodier, J.A., eds., UNESCO-World Meteorological Organization, A Contribution to the International Hydrologic Programme: Paris, France, p. 27-64.

Water Resources Council, 1966, Drought in northeastern United States, a third appraisal: Water Resources Council Report to the President, $22 \mathrm{p}$.

Subrahmanyam, V.P., 1967, Incidence and Spread of-Continental drought: World Meteorological Organization/International Hydrological Decade Report no. 2, 51 p.

Talley, J.H., 2000, The drought and flood of 1999, in First State Geology: Delaware Geological Survey, vol. 18, no.1, p. 1-2. 
